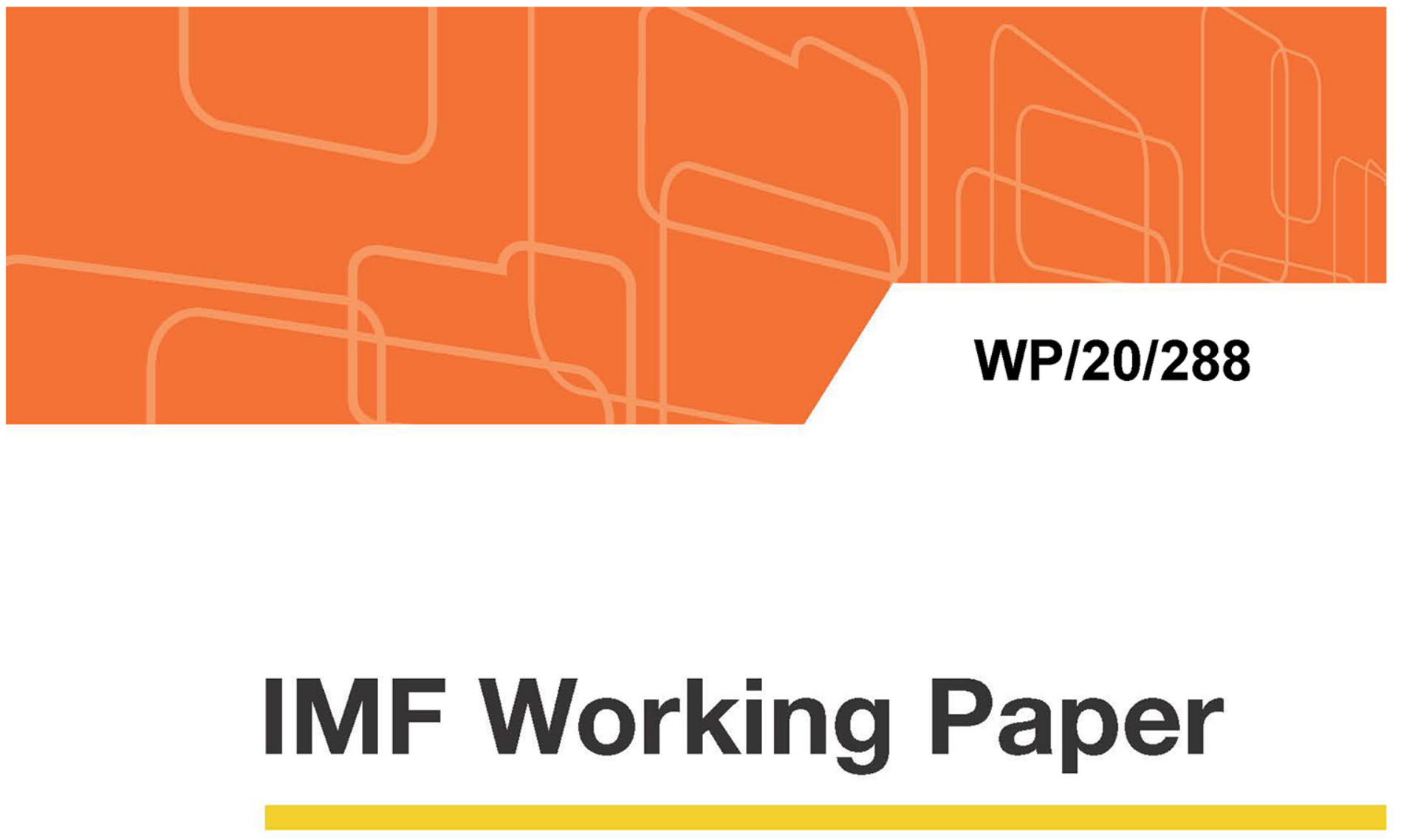

\title{
Managing External Volatility: Policy Frameworks in Non- Reserve Issuing Economies
}

by Hélène Poirson, Nathan Porter, Ghada Fayad, Itai Agur, Ran Bi, Jiaqian Chen, Johannes

Eugster, Stefan Laseen, Jeta Menkulasi, Kenji Moriyama, Céline Rochon, Katsiaryna Svirydzenka, Camilo Tovar, Zhongxia Zhang, Aleksandra Zdzienicka

IMF Working Papers describe research in progress by the author(s) and are published to elicit comments and to encourage debate. The views expressed in IMF Working Papers are those of the author(s) and do not necessarily represent the views of the IMF, its Executive Board, or IMF management.

$$
\text { I N T E R N A T I O N A L M O N E T A R Y F U N D }
$$




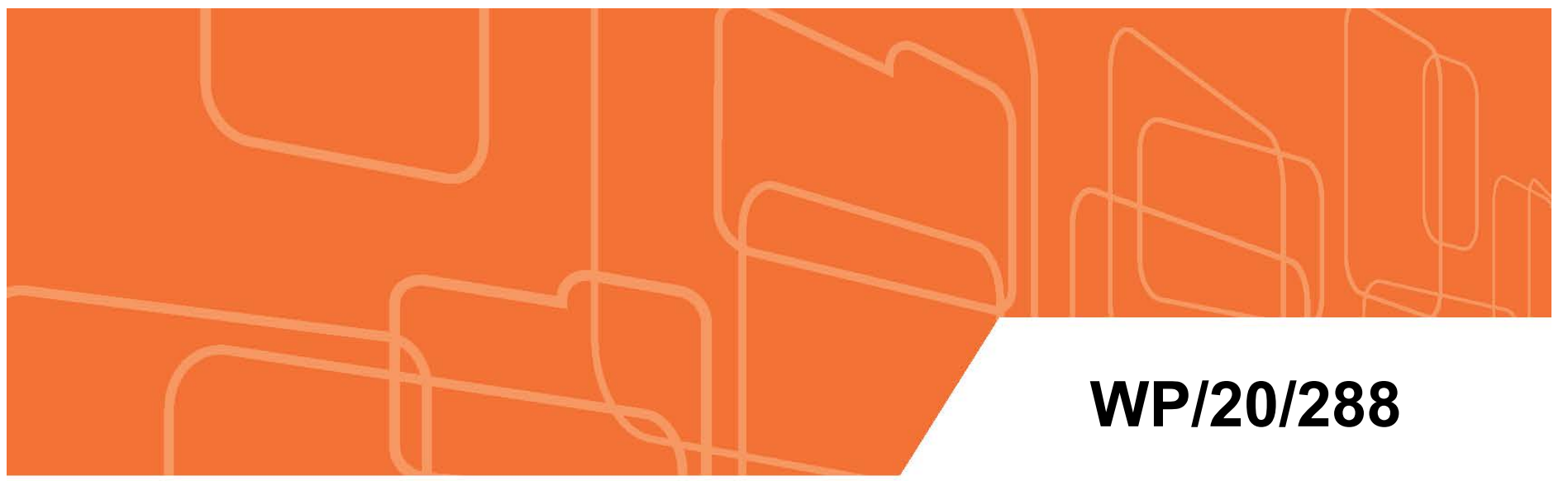

\section{IMF Working Paper}

\section{Managing External Volatility: Policy Frameworks in Non- Reserve Issuing Economies}

by Hélène Poirson, Nathan Porter, Ghada Fayad, Itai Agur, Ran Bi, Jiaqian Chen, Johannes

Eugster, Stefan Laseen, Jeta Menkulasi, Kenji Moriyama, Céline Rochon, Katsiaryna Svirydzenka, Camilo Tovar, Zhongxia Zhang, Aleksandra Zdzienicka

IMF Working Papers describe research in progress by the author(s) and are published to elicit comments and to encourage debate. The views expressed in IMF Working Papers are those of the author(s) and do not necessarily represent the views of the IMF, its Executive Board, or IMF management.

$$
\text { I N T E R N A T | O N A L M O N E T A R Y F U N D }
$$


IMF Working Paper

Strategy, Policy, and Review Department

\title{
Managing External Volatility: Policy Frameworks in Non-Reserve-Issuing Economies \\ Prepared by Hélène Poirson, Nathan Porter, Ghada Fayad, Itai Agur, Ran Bi, Jiaqian \\ Chen, Johannes Eugster, Stefan Laseen, Jeta Menkulasi, Kenji Moriyama, Céline Rochon, Katsiaryna Svirydzenka, Camilo Tovar, Zhongxia Zhang, Aleksandra Zdzienicka $^{1}$
}

Authorized for distribution by Rupa Duttagupta

December 2020

\section{IMF Working Papers describe research in progress by the author(s) and are published to} elicit comments and to encourage debate. The views expressed in IMF Working Papers are those of the author(s) and do not necessarily represent the views of the IMF, its Executive Board, or IMF management.

\begin{abstract}
Since the global financial crisis, non-reserve-issuing economies (NREs) have been highly sensitive to episodes of external pressures. With monetary policy independence constrained by this sensitivity, many NREs have utilized other policy instruments. This paper confirms the vulnerability of NREs to external shocks and finds that in some circumstances managing such shocks with multiple instruments can both lessen the policy response required from any one policy tool to financial and external shocks and increase the effectiveness of policies in stabilizing macrofinancial conditions. Effectiveness however does not always imply appropriateness, which rests on an evaluation of potential trade-offs and unintended consequences.
\end{abstract}

JEL Classification Numbers: E44, E52, E58, F31, F32, F62

\footnotetext{
${ }^{1}$ The authors would like to thank Marco Arena, Vivek Arora, Gabriel Di Bella, Rupa Duttagupta, Gaston Gelos, Lucyna Gornicka, Vikram Haksar, Armine Khachatryan, Vladimir Klyuev, Petya Koeva Brooks, Martin Kaufman, Varapat Chensavasdijai, Gavin Gray, Shakill Hassan, Dong He, Jonathan Ostry, Mahvash Qureshi, Yu Shi as well as the Bank of Israel, Bank of Mexico, and Bangko Sentral ng Pilipinas for valuable comments, and Arshia Karki, Chengyu Huang, Tessy Vasquez, and Tiffany Wang for outstanding research assistance.
} 
Keywords: Monetary policy, foreign exchange intervention, policy transmission and effectiveness, macroprudential policy, capital flow management measures

Authors' E-Mail Addresses: HPoirson@imf.org; NPorter@imf.org; GFayad@imf.org;

IAgur@imf.org; RBi@imf.org; JChen@imf.org; JEugster@imf.org;

Stefan.Laseen@riksbank.se; JMenkulasi@imf.org; KMoriyama@imf.org; CRochon@imf.org;

KSvirydzenka@imf.org; CTovar@imf.org; ZZhang2@imf.org;AZdzienicka@imf.org. 
Abstract

I. Introduction 1

II. Spillovers from External Conditions $\underline{9}$

III. Effectiveness of Policy Combinations $\underline{18}$

A. The Use of Additional Instruments.... $\underline{18}$

B. Monetary Policy Transmission and the Impact of Additional Instruments on FXI

Effectiveness and the Monetary Policy Response $\underline{20}$

C. Interest Rate Policy under Extreme External Pressure and FX Market Liquidity ......... 27

D. The Impact and Effectiveness of Policy Packages................................................. 29

1. Monetary Policy, FXI, and the Impact of CFMs .......................................................... 29

2. Monetary, Fiscal, and Macroprudential Policies, when Monetary Policy is Constrained............ $\underline{32}$

IV. Conclusion $\underline{35}$

Box

III. 1. The Impact of Interest Rate Policy in the Face of External Pressure $\underline{28}$

\section{Tables}

III.1. Correlations Between Use of Different Policy Tools $\underline{20}$

III.2. Liquidity Conditions in the FX Market Around the December 16, 2014 Hike in the Key Policy Rate

\section{Figures}

II.1. External Factors, Growth, and Inflation

II.2. External Factors and the NEER

II.3. The Drivers of the Policy Rate.

II.4. External Financial Conditions and the Policy Rate

II.5. The Response of Policy Rates to the FFR and Other Policy Tools......

II.6. External Conditions and Long-term Financial Conditions

III.1. The Use of Additional Instruments

III.2. The Effect of a Monetary Policy Shock

III.3. IRF of Inflation to the NEER.

III.4. IRF of Output and Inflation to Credit $\underline{24}$

III.5. Additional Policy Tools Delay the Monetary Policy Response to Credit and Exchange Rate

Gaps $\underline{26}$

III.6. Impact of an External Financing Shock

III.7. Impact of a Domestic Demand Shock

III.8. The Policy Trade-off between Inflation and Output Volatility .... $\underline{32}$

III.9a Monetary Policy Rule: Unconstrained Taylor Rule 
Figure III.9b. Monetary Policy Rule: Max (0, Unconstrained Taylor Rule)................... $\underline{34}$

Annex

I. Monetary Policy, FXI, and the Impact of CFMs ......................................................... $\underline{36}$

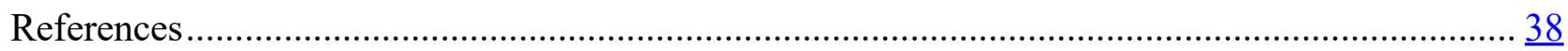




\section{GLOSSARY}

$\begin{array}{ll}\text { AE } & \text { Advanced Economy } \\ \text { CBR } & \text { Central Bank of Russia } \\ \text { CDS } & \text { Credit Default Swap } \\ \text { CFM } & \text { Capital Flow Management Measures } \\ \text { CPI } & \text { Consumer Price Index } \\ \text { DSGE } & \text { Dynamic Stochastic General Equilibrium } \\ \text { EM } & \text { Emerging Market } \\ \text { FX } & \text { Foreign Exchange } \\ \text { FXI } & \text { Foreign Exchange Intervention } \\ \text { GFC } & \text { Global Financial Crisis } \\ \text { IRF } & \text { Impulse Response Function } \\ \text { IT } & \text { Inflation Targeting } \\ \text { MPM } & \text { Macroprudential Measure } \\ \text { NEER } & \text { Nominal Effective Exchange Rate } \\ \text { NRE } & \text { Non-reserve-issuing Economies } \\ \text { UMP } & \text { Unconventional Monetary Policies } \\ \text { ZLB } & \text { Zero Lower Bound }\end{array}$




\section{INTRODUCTION}

While globalization has produced many benefits, the accompanying size and volatility of capital flows also posed policy challenges for small financially integrated non-reserve issuing economies (NREs). ${ }^{1}$ The global financial crisis (GFC) led systemic economies to undertake unprecedented measures to support the recovery and which produced abrupt swings in risk sentiment, volatility in financing conditions, and large movements in capital flows. As such the post-GFC period saw periods of pressure on NREs affecting local financing conditions and exchange rates through volatile capital flows and spreads, and raising concerns about economic and financial stability. ${ }^{2}$ Indeed, this period demonstrated how external financial conditions can complicate policymaking in NREs.

Using a sample that covers both the pre-GFC period and its immediate aftermath, the paper confirms NREs' vulnerability to spillovers (Section II). In line with the extensive literature on global spillovers from large economies (e.g. Rey, 2015 or Arregui et al., 2018), analytical work in this paper confirms that NREs are heavily affected by both real and financial external conditions, which can affect policy independence and hamper policy settings in these countries. ${ }^{3}$ This paper considers the impact of changes in external financial conditions on policy independence in two different ways: first, the effect on the policy rate chosen by policymakers; and, second, the direct impact on domestic financial conditions (irrespective of policy rate changes).

Among NREs, both advanced economies (AEs) and emerging markets (EMs) have revised their policy frameworks over the past decade or so. EMs have continued their transition towards inflation targeting as a key monetary policy objective, moving away from monetary and exchange rate targets. Both advanced economies and emerging markets have also made greater use of macroprudential measures (MPMs) to limit the build-up of systemic financial risks. Some EMs have also increased their use of capital flow management measures (CFMs). Section III outlines how the use of alternate - more targeted-

\footnotetext{
${ }^{1}$ For the purpose of this analysis, "reserve currency issuers" refers to issuers of the major reserve currencies (euro, pound, US dollar, and yen). Such reserve issuing countries include all euro area countries, Japan, the U.K., and the U.S. Other countries that issue a reserve currency held in relatively small quantities by governments and institutions as part of their foreign reserves will be considered NREs.
${ }^{2}$ By definition, NRE central banks do not have a function of lender of last resort of foreign exchange (FX) liquidity. However, this paper's view is that such function would not be critical during non-stress periods. For the importance of the FX lender of last resort function in NREs during severe stress periods, see discussion in IMF (2013a).

${ }^{3}$ Monetary policy independence is understood as the ability of NRE central banks to set interest rates independently of international rates (Aizenman et al., 2013).
} 
measures such as FXI, MPMs, and CFMs have in general been complementary to that of traditional macroeconomic policy tools.

Given the increasing use of policy combinations to manage external volatility by NRE policy makers, this paper considers two important questions: a) what are the conditions under which particular policy combinations may be most effective; and b) what weights should be placed on each instrument to make a combination most effective? This paper provides some elements of a response to these questions, suggesting the need for further policy research (including at the country level). In this paper, effectiveness refers to the extent to which various policy tools and combinations can help dampen volatility in growth and inflation. This, in turn, is based on how key macroeconomic aggregates and financial prices (mainly interest and exchange rates) respond to the use of these instruments. Effectiveness is thus intertwined with the transmission channels of macroeconomic and other policies, and any potential interactions between these policies. Effectiveness, however, does not imply appropriateness. ${ }^{4}$ Other factors - including initial conditions, the stage of the financial cycle, macroeconomic policy imbalances, the costs of activating a particular tool as well as any possible unintended consequences which may result from the prolonged use of such tools - also matter for the appropriateness of a particular policy choice.

The paper's key messages relate to the transmission and effectiveness of instruments and different policy combinations:

- NREs'vulnerability to spillovers. In a sample of 11 major EMEs selected to provide broad coverage across regions, domestic policy rates react directly to both external financial conditions and external real factors. There is also a high sensitivity of domestic yields and exchange rates to external financial shocks irrespective of changes in domestic policy rates. Both these findings suggest a loss of monetary policy independence. Spillover analysis using a large sample of 66 NREs confirms their vulnerability to global financial shocks. However, NREs with a more flexible exchange rate regime, and those which deploy alternative, more targeted instruments, seem to regain some monetary policy autonomy.

- Transmission and effectiveness of policy instruments. In the sample of 11 major EMEs, interest rate-based monetary policy can effectively influence both output and inflation and transmits through long-term interest rates. Exchange rate flexibility plays a critical role as a buffer for NREs, although foreign exchange intervention (FXI) seems capable of mitigating appreciation and depreciation pressures at most in the short run, given the significant impact on the pace of foreign exchange (FX), when reserves are adequate and macroeconomic imbalances small. The impact of FXI is comparatively larger for countries with CFMs as this reduces offsetting private capital flows. During periods of high external pressure, however, interest rate policy can be helpful. The results of panel regression analysis for a large sample of 79 NREs indicate that, reflecting the importance of the exchange rate and credit channels, NRE central banks tend de facto to respond to financial and external stability considerations. However, use of alternate

\footnotetext{
${ }^{4}$ A determination of appropriateness is outside of the scope of this paper as it requires a fuller analysis of costs and benefits of the different policy combinations. See Basu and others (2020) and Adrian and others (2020) on the assessment of optimal policy combinations in response to external shocks.
} 
instruments targeted specifically at these objectives seems to limit the need for them to use monetary policy for these considerations.

- Effectiveness of policy packages. There are important interactions between policy instruments which affect the impact of an overall policy package. These depend on the nature of the shock and the constraints on monetary policy transmission. In the case of the lower bound constraint on monetary policy, the results of a novel open-economy dynamic stochastic general equilibrium model illustrate that a combined policy response to a global supply shock that lowers inflation can be more effective than a response that relies on a single instrument.

These initial findings lay down some markers for further policy research on integrated policy frameworks. Policy and analytical work on these issues has progressed at a rapid clip in recent years, including under the IMF's Integrated Policy Framework (IPF) umbrella. Basu et al. (2020) provide a comprehensive model that jointly analyzes monetary, exchange rate, macroprudential and capital flow management policies and analytically solves for their optimal combination, including how these policies interact with different frictions and with each other. Adrian et al. (2020) use a fullyfledged empirically oriented model which enables them to quantify the policy tradeoffs countries face and how different policy tools can be used to mitigate them. Fayad and Poirson (2020) use a case study approach for an in-depth assessment of the unorthodox policy responses of seven small open economies with flexible exchange rate regimes to external shocks. For emerging markets in Asia, Finger and Lopez Murphy (2019) find that monetary policy responds, in addition to inflation and output gaps, to an array of external and domestic influences, including the US policy rate, capital flows, the exchange rate, and credit growth. Gelos et al. (2019) empirically show for EMs in general that monetary policy may not always be effective in addressing external shocks. BrandaoMarques et al. (2020) find that macro-policies are effective in 'leaning against' financial vulnerabilities and best accompanied by looser, not tighter, monetary policy.

This paper is structured as follows. Section II establishes the sensitivity of NREs to external conditions by estimating the effect of external real and financial shocks on key macroeconomic variables and on the policy rate. Section III documents the evolving use of alternative policy tools by NREs (III.A) and illustrates how such use is able to help manage macroeconomic developments, including by investigating the transmission and effectiveness of traditional monetary policy and how the use of alternate tools affects FXI effectiveness and the monetary policy reaction (III.B). It also outlines the example of Russia where interest rate policy was an effective part of the policy package to stem extreme external pressure in 2014-2015 (III.C) and illustrates the impact and effectiveness of alternative policy responses (III.D). Section IV concludes.

\section{SPILlOVERS FROM EXTERNAL CONDITIONS}

NREs are highly sensitive to changing external demand and financial conditions, even outside systemic risk-off events. This sensitivity can constrain their monetary policy independence. This could call for the need to deploy other policy tools to assist in achieving domestic policy objectives. 
To show this sensitivity, the paper applies a pooled panel structural VAR, using monthly data from 2000 to 2016 from eleven emerging markets. ${ }^{5}$

The model includes factors summarizing external real and financial conditions, growth, inflation, the nominal effective exchange rate (NEER), the policy rate and long-term interest rates, and domestic credit. In this exercise, external conditions are captured by: (1) financial factors (namely, country-specific EMBI and CDS spreads, US term premia, VIX) and (2) real factors (namely, external demand, terms of trade, and relevant commodity prices). The

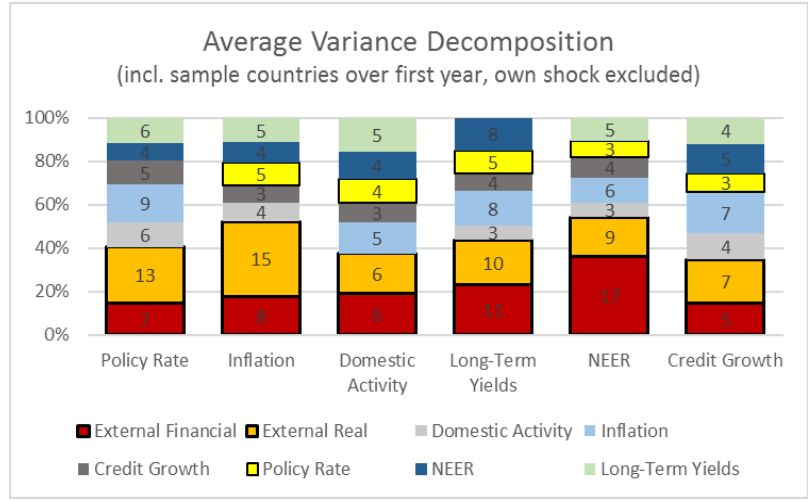
model is estimated using six lags and a Cholesky identification, which orders external factors before domestic activity, prices, and credit. Exchange rates and interest rates are ordered last. The latter variables react contemporaneously to all previous ones, but they affect those only with a lag. Specifically, the baseline ordering is the following: external financial conditions, external real conditions, domestic activity, CPI inflation, private credit growth, the policy rate, long-run yields, and the NEER. The results are robust to different orderings. ${ }^{6}$

The variance decomposition suggests that real and financial external shocks are the largest individual drivers of volatility in small financially integrated NREs. External financial conditions contribute the most to movements in domestic yields and the exchange rate, and thus these spillovers constrain the monetary policy independence enjoyed by NREs. ${ }^{7}$ On the other hand, external real factors are the most important for other variables. The importance of these factors is also confirmed in their effect on the dynamics of key macroeconomic variables and financial prices (Figure II.1). A strengthening of real external conditions on the one hand raises domestic activity and inflation, and leads to an appreciation of the currency. Tighter external financial conditions on the other hand, depreciate the exchange rate, which temporarily translates into inflationary pressures despite a protracted negative effect on domestic activity.

\footnotetext{
${ }^{5}$ The sample used for the analysis in this section includes Brazil, Chile, India, Indonesia, Malaysia, Mexico, Peru, Poland, Thailand, Turkey, and South Africa providing coverage of major emerging markets across regions, with roughly similar levels of development and reliance on interest rates for monetary policy (despite varying degrees of intervention). It also reflects data availability constraints - related to data underpinning the external factors - for some other economies.

6 The results in this section from the pooled VAR are based on the average reactions across the countries in the sample, and thus mask the cross-country variation in the duration and the amplitude of the impacts of shocks. A country-specific analysis, not shown here, revealed that while the impulse responses from the panel generally represent the reaction of a clear majority of the countries, there are often a few exceptions. Aggregate results should be interpreted with theses country differences in mind.

${ }^{7}$ The findings are in line with Chapter 3, April 2017 GFSR. Sensitivity to external spillovers could imply limits to monetary policy independence, to the extent that it constrains domestic policy's ability to respond optimally to foreign financial conditions.
} 


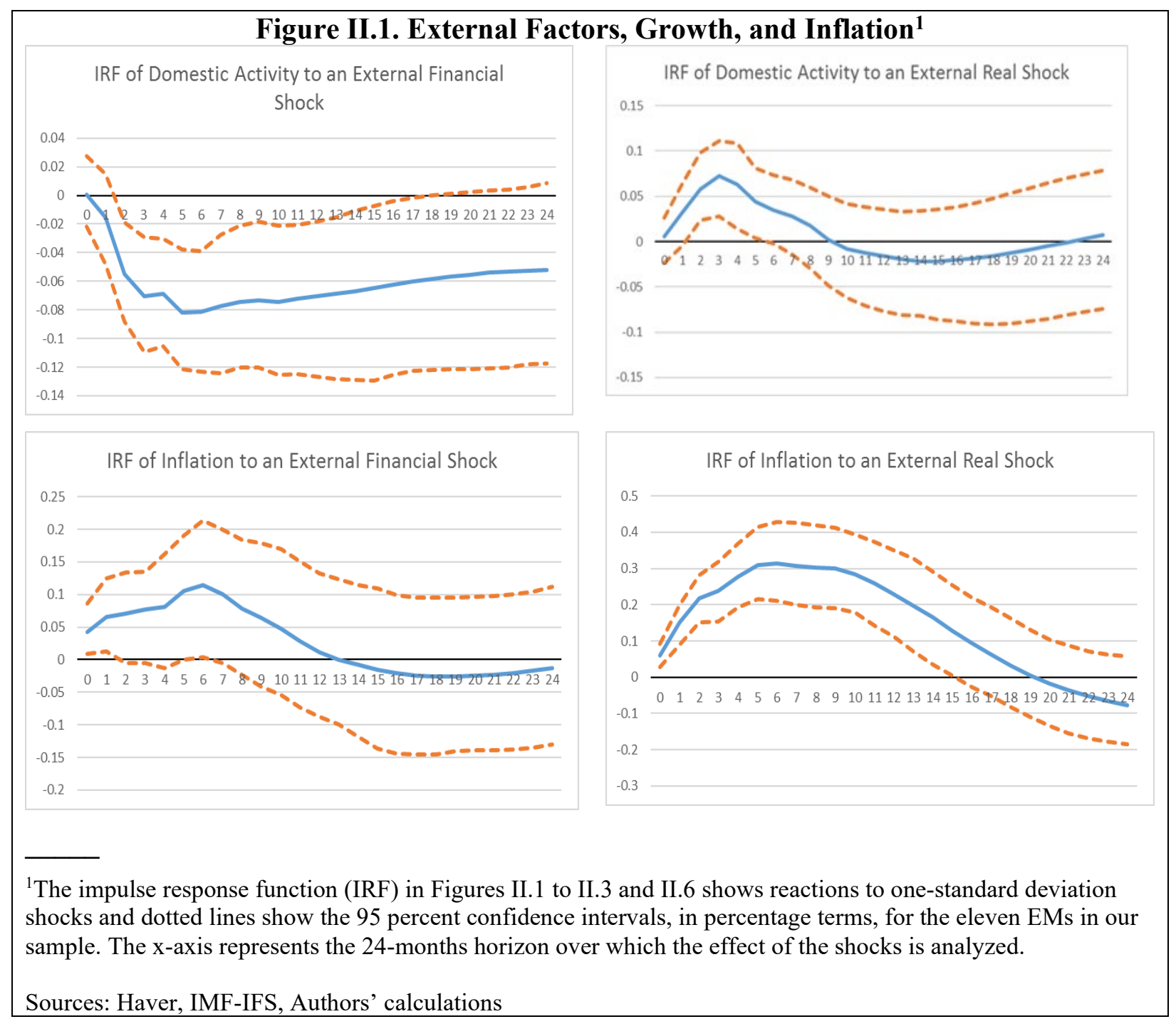

Exchange rates act as an important buffer against external shocks in many NREs. Positive real external shocks, such as shocks to commodity prices or external demand, lead to a nominal appreciation of the domestic currency, while external financial shocks associated with tighter global financial conditions lead to currency depreciation (Figure II.2). Exchange rate flexibility thus moderates the impact of real and financial shocks. 


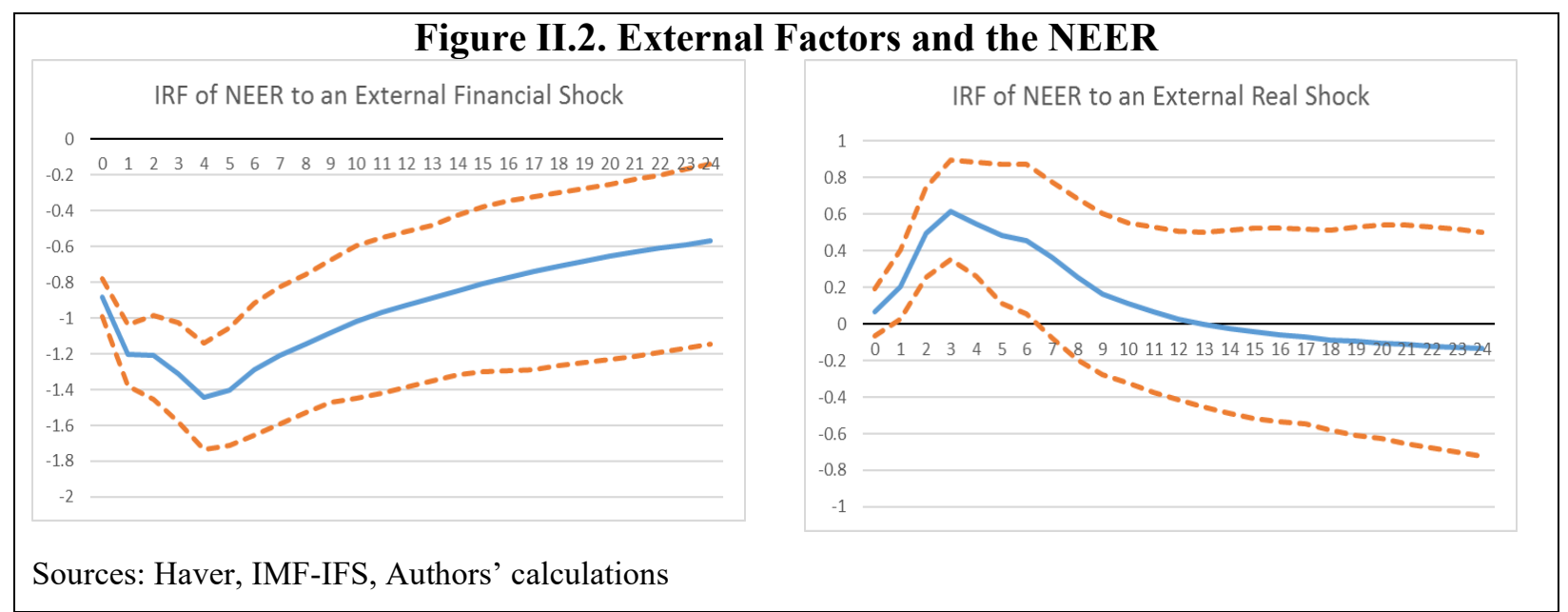

The concept of monetary policy independence discussed so far relates to the impact of changing external real and financial conditions on domestic financial conditions irrespective of policy rate changes.

There is another different, but related, way to consider independence. This second concept of independence relates to the impact of changes in external conditions on the policy rates chosen by policymakers. ${ }^{8}$ Here the impact depends on the nature of the external shock, as well as on the extent to which other tools (e.g. CFMs and MPMs) are used to reduce the sensitivity of domestic conditions to external conditions.

The impulse responses derived from the estimated VAR models illustrate the dynamic responses of the policy rate to domestic and external shocks. In line with large AEs, own inflation and output are important drivers of the policy rate in NREs. However, exchange rates, credit, and external real and financial factors also have a statistically significant influence on the policy rate. While the specific results vary across countries, spillovers vary based on the nature of the shock and can be channeled either through exchange rate or credit channels (Figure II.3):

- Spillovers. Central banks' policy rates respond to external conditions, with positive real external shocks and tighter external financial conditions leading to higher domestic policy rates. ${ }^{9}$ The impact of overall financial external shocks (i.e., those encompassed in the external factor) is, however shorter-lived. The initial increase, possibly to stem capital outflows, peaks around six months, given a more persistent positive effect on long-term yields (Figure II.6) and the significant contractionary effect on domestic activity (Figure II.1). ${ }^{10}$

\footnotetext{
${ }^{8}$ Policy rates in NREs are affected by external factors, not just by domestic inflation and output as in larger advanced economies. That is, the de facto policy rule includes factors beyond those in the standard Taylor rule. Käfer (2014), Aizenman, Hutchison and Noy (2011), and Muñoz and Schmidt-Hebbel (2014) investigate such 'augmented' Taylor rules.

${ }^{9}$ While factor loadings differ somewhat between countries, a one-standard deviation shock corresponds roughly to a two-standard deviation change in the EMBI (equivalent to roughly 250 basis points) or the 5 -year CDS spread (equivalent to roughly 265 bps) or a three-standard deviation (20-unit) change in the VIX.

${ }^{10}$ IMF (2013a) shows that the duration of global financial shocks is relatively short.
} 
- An effective appreciation of exchange rates leads to a significant and persistent reduction of the policy rate, reflecting lower expected inflationary pressures.

- Rapid private credit growth can result in a tightening of interest rate policy over time in order to avoid economic overheating or balance sheet strains.

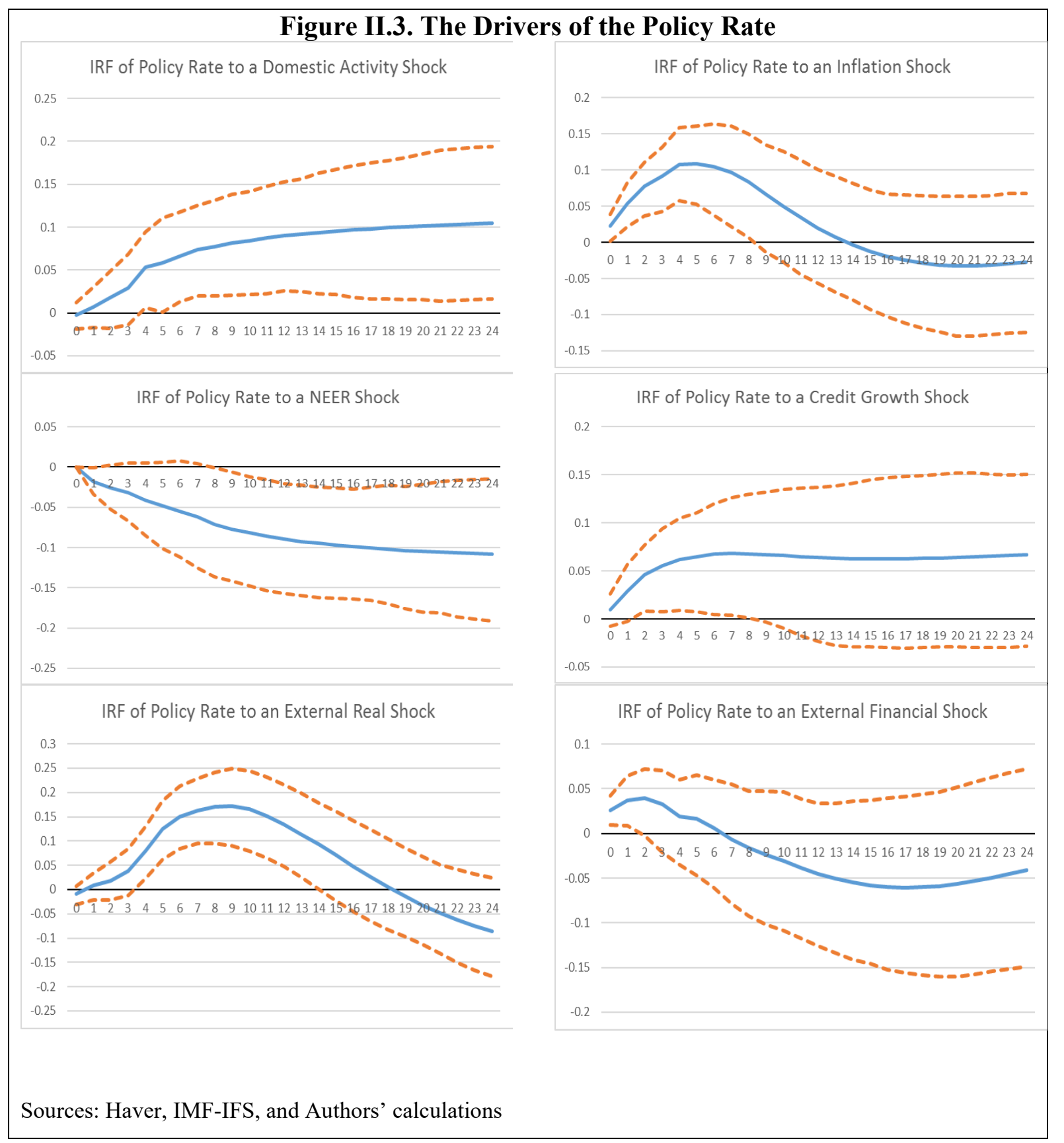

We then analyze the role of other policy measures in shaping the monetary policy response of NREs to global financial shocks. Using the local projection method developed by Jorda (2005), we first estimate the average dynamic response of monetary policy rates to external financial conditions in a 
large sample of 66 NREs during the period 1996Q1 to 2015Q4. In particular, we estimate the average dynamic response of monetary policy rate $y$ in country $i$ to global financial shocks GFS for each future period $k(=1, \ldots, 8)$ :

$y_{i, t+k}-y_{i, t}=\alpha_{i}^{k}+\vartheta_{t}^{k}+\beta^{k} G F S_{t}+\varepsilon_{i, t}^{k}$

where $\alpha_{i}^{k}$ are country fixed effects included to control for unobserved cross-country heterogeneity; $\vartheta_{t}$ are time fixed effects to control for other global shocks. ${ }^{11} G F S_{t}$ are approximated by: (i) the Federal Funds Rates and (ii) the VIX. The estimates are based on clustered robust standard errors.

Subsequently, we estimate Equation (1) controlling for country-specific factors and for exchange rate and monetary policy regimes. In particular, the exchange rate regimes are classified based on the Reinhart-Rogoff classification into three groups: fixed, intermediate, and flexible. ${ }^{12}$ Members of monetary and currency unions, and countries without separated currency tenders are excluded. Countries with inflation targeting are identified based on their central banks' information and IMF exchange rate arrangement classification. Finally, we extend Equation (1) to measure the impact of additional policies $\left(p_{i t}\right)$ in shaping monetary policy reaction to foreign financial shocks:

$y_{i, t+k}-y_{i, t}=\alpha_{i}^{k}+\vartheta_{t}^{k}+\beta^{k} G F S_{t}+\delta^{k} G F S_{t} p_{i, t}+\gamma_{i}^{k} p_{i t}+\varepsilon_{i, t}^{k}$

The results confirm that NREs' policy rates react directly to Fed policy rate changes, with increases in the US policy rate raising domestic policy rates (Figure II.4). The speed of this response differs depending on country-specific factors and policy frameworks, including financial development, openness, and exchange rate regimes (in line with past studies of policy independence such as IMF, 2013b, Ricci and Shi, 2016), and Zdzienicka et al, 2015). In particular, policy rates in countries with a fixed exchange rate regime react immediately to such shocks, while the impact is delayed for NRES with a more flexible exchange rate regime - it becomes statistically significant only after two quarters for IT countries with a floating exchange rate regime and after four quarters for countries with intermediate exchange rate regimes. An increase in the VIX meanwhile-which directly tightens EM financing conditions through the risk premia-leads to a reduction in NRE policy rates.

The results of this analysis also suggest that the response of monetary policy is softened for countries using other policy tools (Figure II.5). ${ }^{13}$ For instance, the use of MPMs and CFMs for various objectives (including to safeguard systemic financial stability) seems as a side effect to dampen the reaction of monetary policy in countries with a more flexible exchange rate regime. This finding is unsurprising given that these policy tools seek to reduce the sensitivity of domestic economic and

\footnotetext{
${ }^{11}$ Results — available upon request—are robust to different lags, different measures of global financial conditions (e.g., U.S. financial cycles -IMF (2015)), and additional controls (e.g., financial crises, recessions).

12 Dataset retrieved from https://carmenreinhart.com/exchange-rate/.

${ }^{13}$ Zdzienicka, et. al. (2015).
} 
financial conditions to external shocks. Notably, the impact of CFMs is only significant in the shortrun (first 3 quarters) while that of MPMs is generally less significant but longer-lasting. 


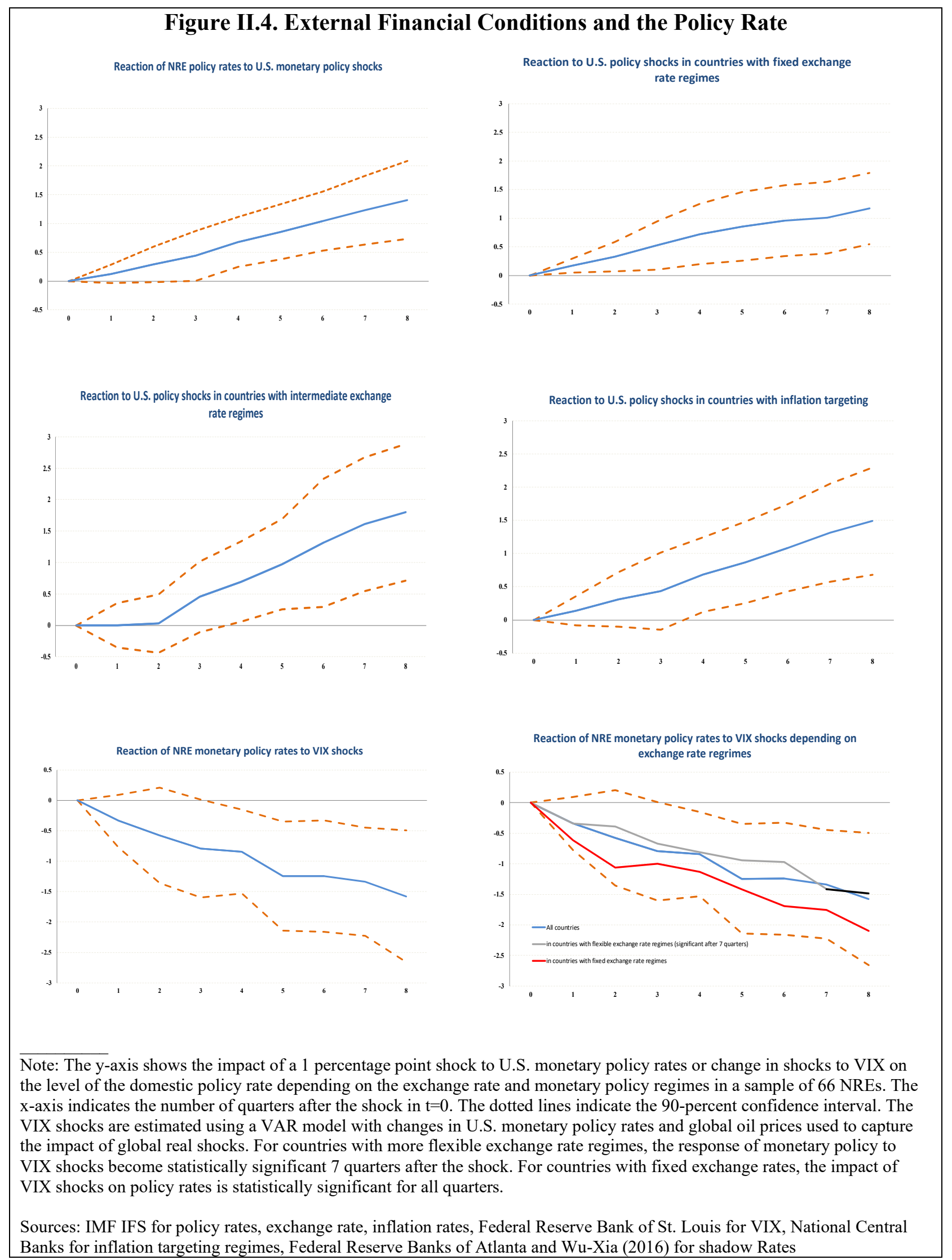




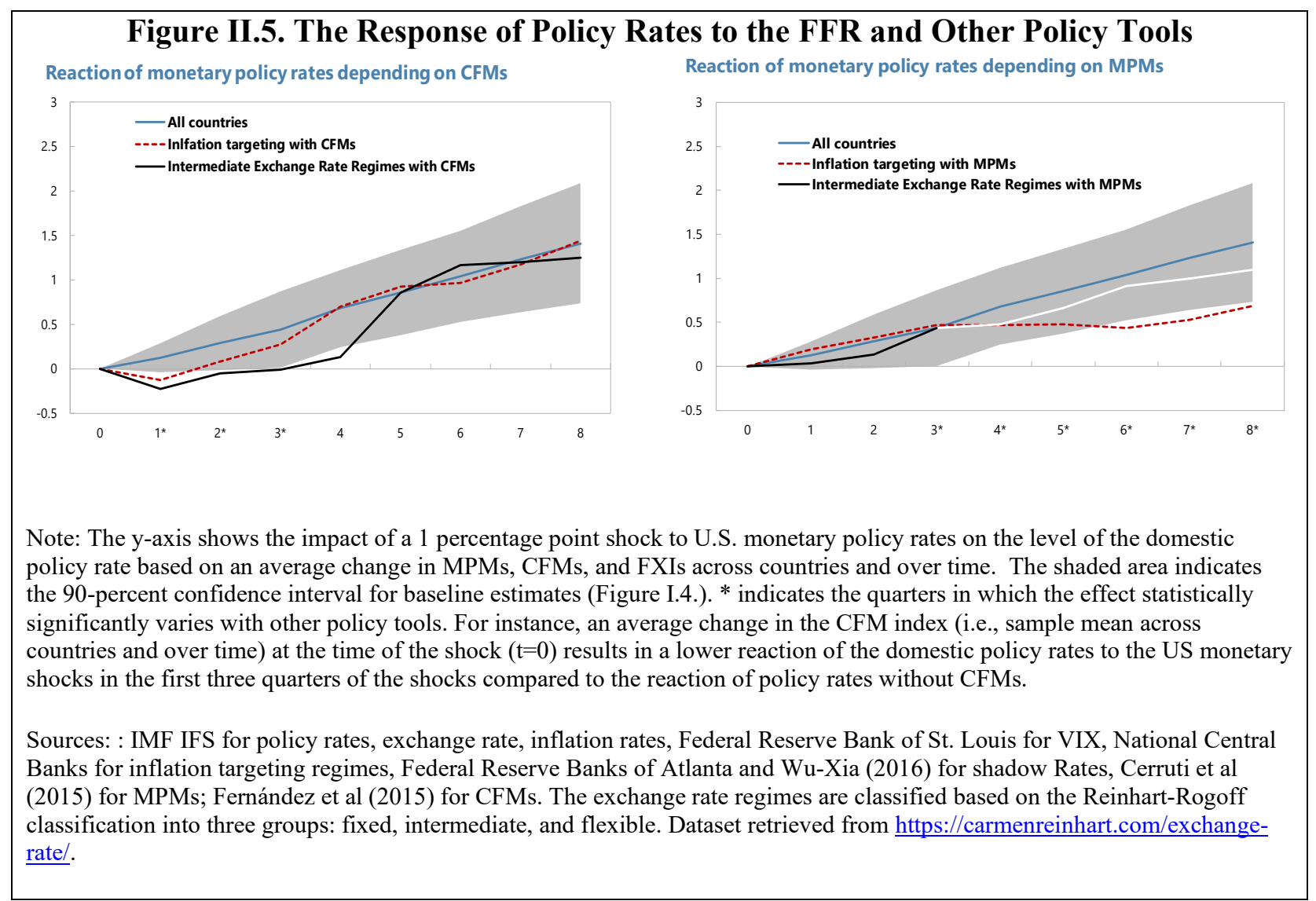

Last, beyond the impact on the policy rate, changes in external conditions (especially financial conditions) significantly affect domestic financial conditions directly (Figure II.6). Stronger real and tighter financial external conditions significantly raise longer-term bond yields. This is independent of changes in the policy rate, and hence suggest a loss of monetary policy independence.

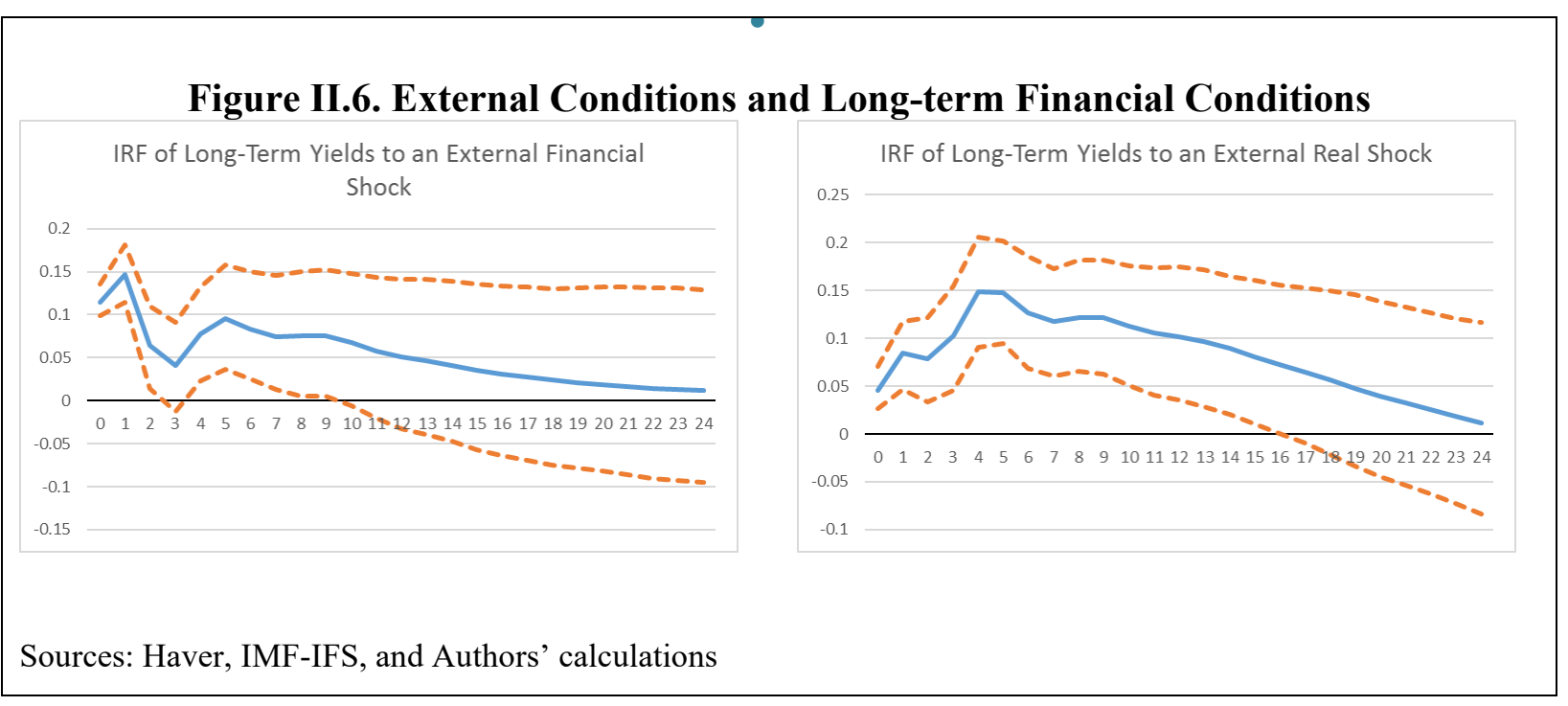


In sum, external conditions are important for economic and financial developments in NREs, and they constrain policy independence. There are a number of reasons for this. First, NRE central banks face more pressures on exchange rates through volatile capital flows than reserve issuers. Second, NREs face significant pass-through of exchange rate fluctuations to inflation, although to varying degrees depending on the extent of the credibility of the central bank. Third, some NREs are subject to large FX balance sheet mismatches. These factors create trade-offs for central banks beyond the standard trade-off between output and inflation summarized by the Phillips curve, further complicating monetary policymaking.

\section{EfFectiveness of Policy Combinations}

This section focuses on how the use of various policy tools is able to help manage macroeconomic developments. Specifically, it discusses (i) the evolving use of alternative policy tools by NREs; (ii) the transmission of shocks and policies to the domestic economy and how the monetary reaction varies depending on the combination of instruments used; and (iii) the effectiveness of policy combinations in addressing the impact of these shocks. Key findings are that despite some loss of independence, monetary policy remains an effective policy tool in part by affecting long term interest rates, and that the impact of policy combinations depends on the nature of the shock, the strength of the transmission channel, and policy constraints. ${ }^{15}$

When confronted by external shocks - whether idiosyncratic or systemic - policymakers can choose from a variety of tools. The traditional tools - interest and exchange rates - relate directly to the country's monetary settings. As confirmed by the findings in Section II, allowing exchange rate flexibility can allow a country to maintain independent control over its domestic interest rate. Such independence is lost if the exchange rate is fixed or stabilized through intervention in a setting where capital flows relatively freely. However, other tools have been increasingly used in recent years as discussed below.

\section{A. The Use of Additional Instruments}

In addition to their reliance on macroeconomic policy, policymakers have made use of additional instruments to help manage rising financial sector stability risks (Figure III.1). Increased use of CFMs in conjunction with other policies, for example, formed an important part of the response to the 2009-12 capital inflow surge. Some countries affected by crises also found CFMs on outflows a helpful tool. Many countries have also made use of MPMs, especially measures designed to limit financial stability risks arising from housing market developments (e.g., loan-to-value and debt-toincome ratios). MPMs are designed to limit systemic risks, including risks arising from the procyclicality in financial markets. Depending on the tool used, the type of variable targeted, and the state of the financial cycle, MPMs can have significant mitigating effects on credit

\footnotetext{
15 This is in line with the findings for ASEAN-5 countries in IMF (2016).
} 
developments; however, empirical evidence on which policies are most effective in reducing the growth rates of overall credit and household and corporate sector credit is still elusive. ${ }^{16}$

The pace of net reserve accumulation slowed in many regions during 2009-15. This slowing reflects the increased use of reserves to manage outflow episodes. However, while there has been increased two-sided intervention since the global financial crisis, not all countries have felt free to use intervention in response to external pressures.

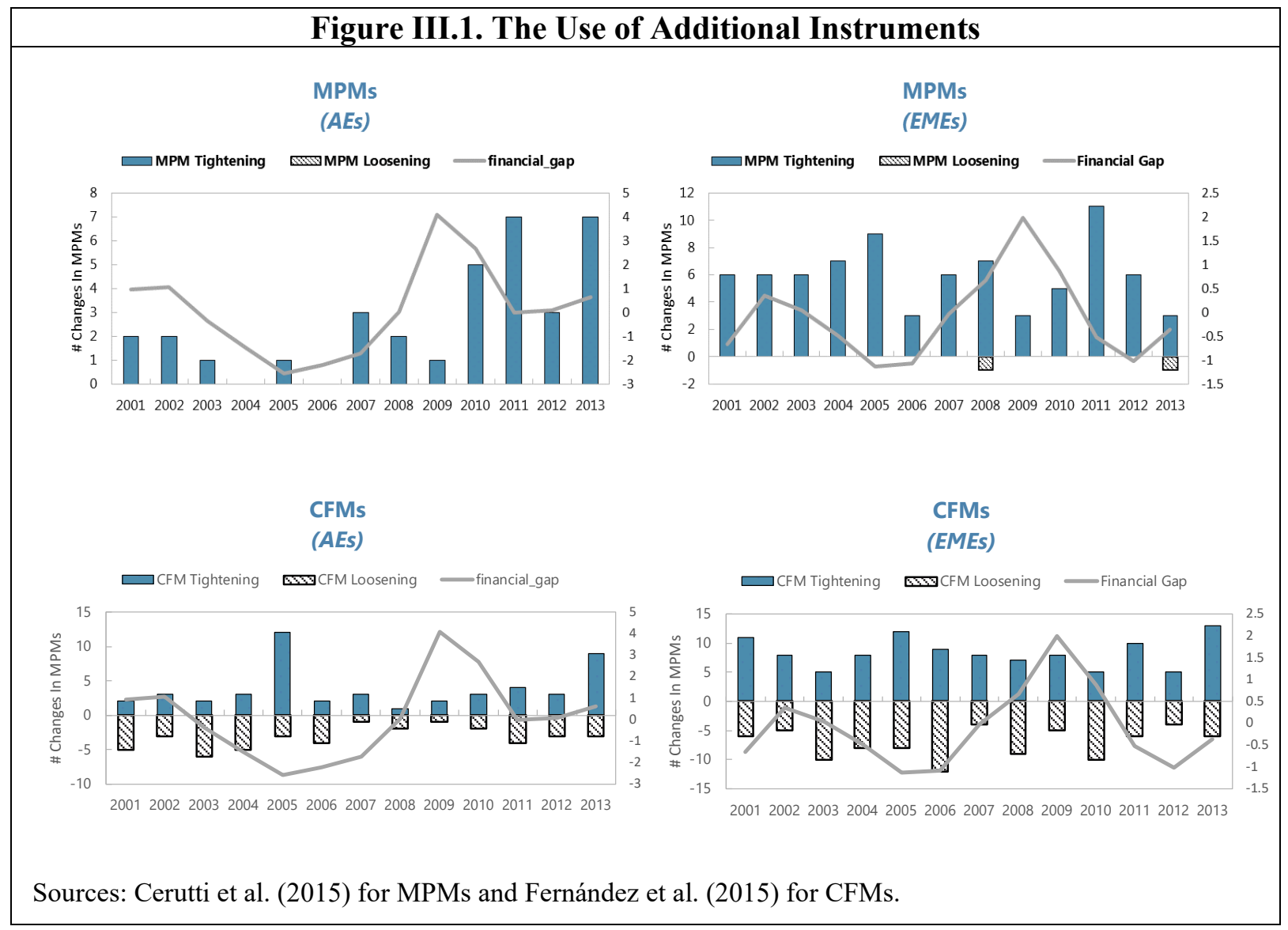

Additional policy tools, including CFMs, MPMs, and intervention, have generally played a complementary role to macroeconomic policies, especially during tightening episodes. Simple correlation analysis indicates that monetary policy, CFMs (on both inflows and outflows), and FXI have been used in complementary ways, while the interactions between monetary policy and MPMs have varied with the stance of monetary policy. ${ }^{17}$ In particular, during a tightening phase, MPMs and monetary policy tend to work in tandem (complements), whereas when monetary

\footnotetext{
${ }^{16}$ See, for instance, Lim and others (2011), Galati and Moessner (2013), Cerutti, Claessens, and Laeven (2015), and Akinci and Olmstead-Rumsey (2016).

${ }^{17}$ IMF (2015b) and IMF (2016).
} 
policy eases, MPMs tend to be tightened (substitutes). Some complementarity (joint tightening and joint easing) also seems to exist between FXIs, MPMs, and CFMs (Table III.1). ${ }^{18}$

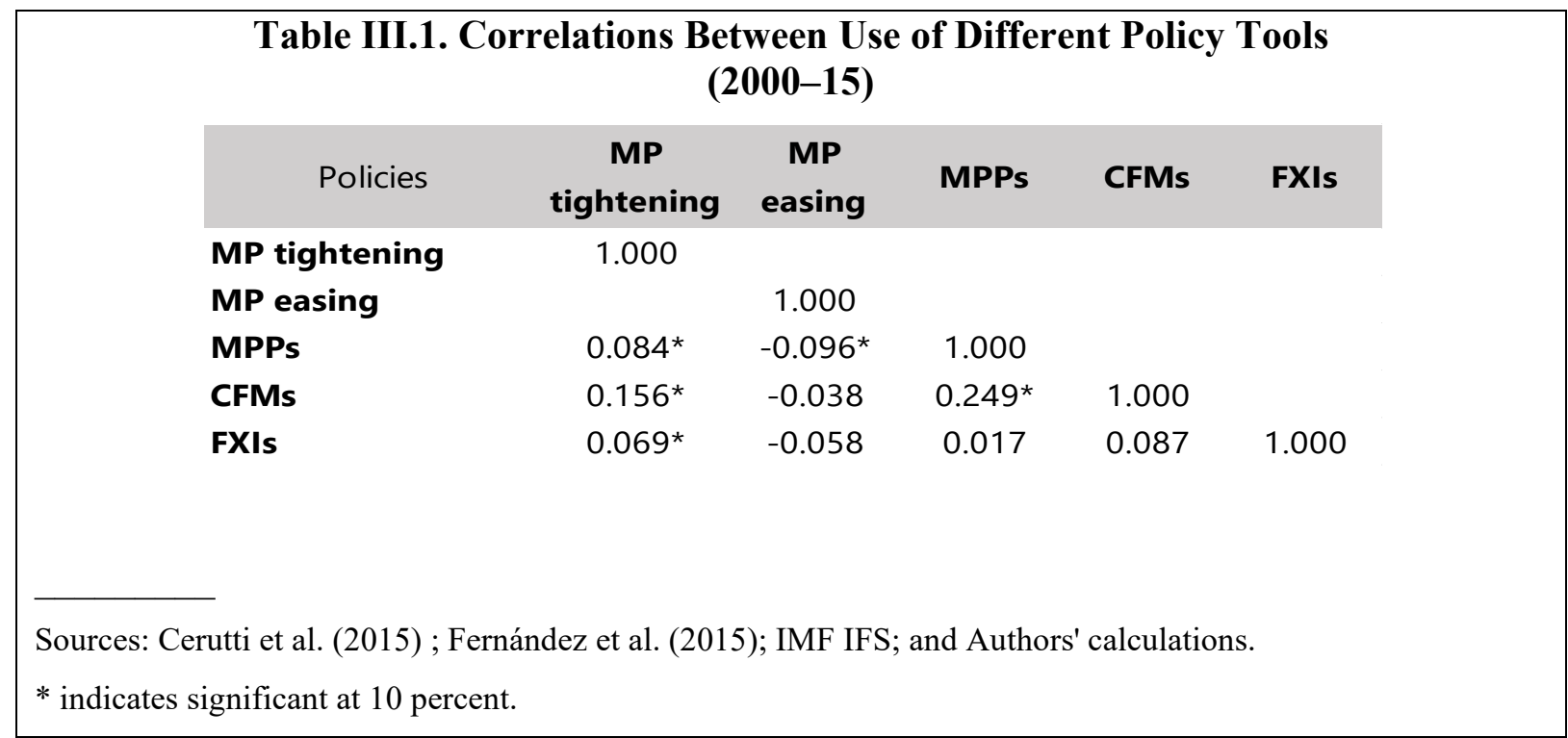

\section{B. Monetary Policy Transmission and the Impact of Additional Instruments on FXI Effectiveness and the Monetary Policy Response}

This section investigates the transmission and effectiveness of traditional monetary policy and how the use of alternate tools affects FXI effectiveness and the monetary policy reaction. Policy rate changes affect output, in part by affecting longer-term interest rates (Figure III.2). Inflation is highly responsive to output, and this Phillips Curve relationship would thus seem an important part of the transmission process. Nonetheless, the direct impact of policy rates on inflation seems to be limited, reflecting a persistent "price puzzle, ${ }^{19}$ " consistent with findings in the literature.

\footnotetext{
${ }^{18}$ Similar pairwise correlations for Asian countries in Bruno, Shin, and Shim (2014) suggest that monetary policy, macroprudential policy, and capital flow measures are all complements (i.e., jointly tightened or eased). Akinci and Olmstead-Rumsey (2015) differentiate housing and non-housing macroprudential tools, finding that the non-housing measures work in tandem with monetary policy (complements), while the housing measures are tightened when monetary policy is eased and vice-versa (substitutes).

19 A persistent "price puzzle" - the finding that positive interest rate shocks result in higher inflation in impulse response analysis - has been a common feature of many monetary policy VARs, both for advanced- and emerging economies since Sims (1992). For advanced economies, alternative identifications (Kim and Roubini, 2000) and the inclusion of additional information (e.g. Bernanke, Boivin and Eliasz, 2005, Banbura, Giannone and Reichlin, 2010) have attenuated or even eliminated the puzzle. For EMs, however, none of the strategies has so far succeeded in eliminating the puzzle.
} 


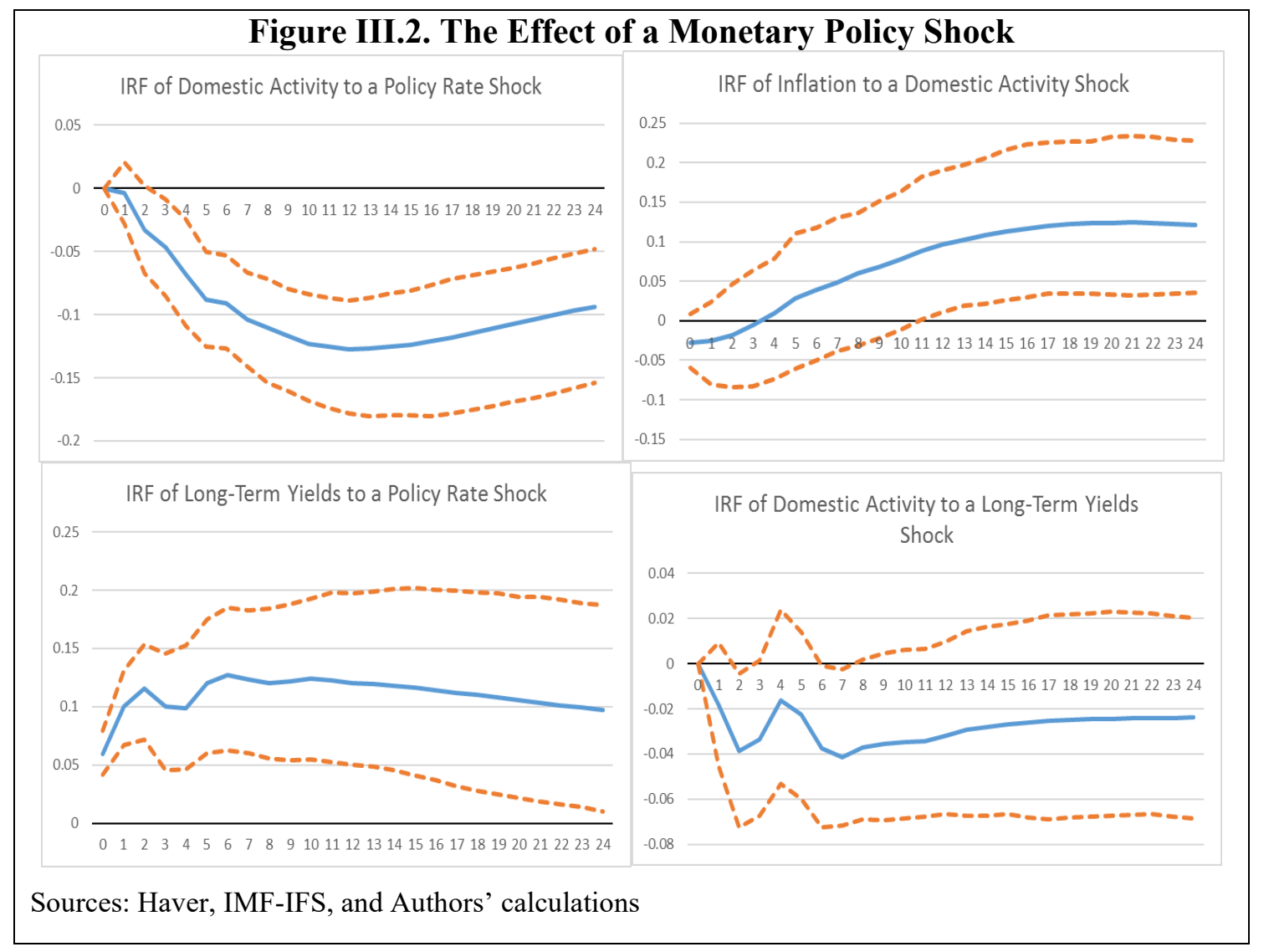

Changes in the nominal effective exchange rate significantly affect both growth and inflation, although the impact is affected by structural characteristics (Figure III.3). Despite the easing effect on monetary policy, nominal exchange rate appreciation feeds through to lower inflation (in line with past studies on FX pass-through, such as Caselli and Roitman, 2019, and Frankel et al., 2012). ${ }^{20}$ However, passthrough depends heavily on the structural and institutional characteristics of the country, including the credibility of the central bank which can limit second-round effects ( Caselli and Roitman, 2019).

With the exchange rate having potent effects on growth and inflation, it has been an important tool for managing volatility in

Figure III.3. IRF of Inflation to the NEER IRF of Inflation to a NEER Shock

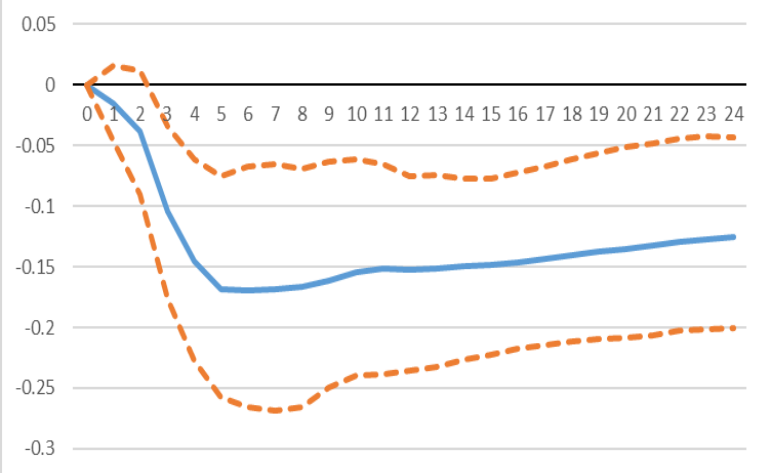

Sources: Haver, IMF-IFS, and Authors' calculations many NREs. Despite the move towards interest rate-based monetary policy, FXI — both spot and non-spot — has proven effective at managing temporary external pressures and their inflationary

\footnotetext{
${ }^{20}$ The domestic activity response to a nominal depreciation likely reflects that appreciation is often associated with expanding external demand for domestic goods.
} 
consequences. The literature provides a mixed picture on the effectiveness of spot FX intervention. Ostry et al. (2012) conclude that evidence for the effectiveness of sterilized FXI in EMs is mixed, but is generally more favorable than in the advanced economy context. Adler and Tovar (2011) found that purchasing foreign currency slowed the pace of appreciation and is more effective at slowing appreciation when the exchange rate is already overvalued, with the amount of intervention appearing to matter more than the mere presence of the central bank in the FX market. Blanchard et al (2013) found that FXI affects exchange rates, and that capital controls and FXI are both complements and substitutes: complements because capital controls decrease the elasticity of flows with respect to relative rates of return, thereby making FXI more powerful; substitutes because both can be used to affect the exchange rate, provided macro policies are appropriate and the flows are having an adverse impact on financial and macroeconomic stability. ${ }^{21}$

Building on Adler and Tovar (2011) and IMF (2013a), the paper estimates the effect of intervention on the exchange rate by applying a two-stage regression to account for endogeneity: intervention affects the exchange rate, but the decision to intervene depends on the movements in the exchange rate. The first stage regression estimates a central bank's FX intervention policy reaction function. The regression is estimated country-by-country, to allow heterogeneity of the response function across countries. Decisions on intervention policy are assumed to depend on recent exchange rate moves and volatility, the level of reserves held by the central bank, and the extent of exchange rate misalignment. ${ }^{22}$

In the second stage, each EM's exchange rate (and its movements) is modeled as a function of short-term interest rates and longer-term sovereign spreads, commodity prices fluctuations, market volatility (as measured by the VIX), as well as the derived central bank intervention from the first stage regression. ${ }^{23}$ Interaction terms were also added to gauge the effect of CFMs and MPMs, as well as fundamentals, on the effectiveness of FX intervention.

The paper finds spot selling FXI to be effective, particularly when CFMs are in place:

\footnotetext{
${ }^{21}$ However, Zhang and Svirydzenka (forthcoming, 2020) find that such a policy, if prolonged can generate unintended consequences via a potential transmission channel from FXI to the FX risk held by banks through their funding conditions. In particular, by limiting the potential for exchange rate volatility, greater FXI incentivizes banks to undertake additional FX lending, which is particularly sensitive to FX volatility.

${ }^{22}$ In order to highlight asymmetry of the response function, the regression is estimated separately when central bank purchases and sells FX.

${ }^{23}$ The exchange rate equation is estimated separately for the case where foreign exchange is purchased, and where it is sold in the first stage. Two types of relationships are estimated: where the dependent variable is (i) the change in level of the bilateral exchange rate against the US\$ (change of natural logarithm); (ii) the appreciation/depreciation of bilateral exchange rate (first difference of i)).
} 
- Selling foreign reserves is effective at absorbing depreciation pressures. Buying foreign reserves is also found to significantly moderate appreciation pressures, particularly when reserves are adequate, capital flows are restricted, inflation is well anchored, the exchange rate is not overvalued, macroeconomic imbalances are limited, and financial markets are less developed. However, while FXI significantly influences the pace of exchange rate changes, this work does not find a statistically significant impact on the exchange rate level.

- When CFMs are in place, selling FX intervention has a larger impact on stemming depreciation pressures, as expected. Countries with CFMs tend to find a larger impact from FXI, as this reduces offsetting private capital flows.
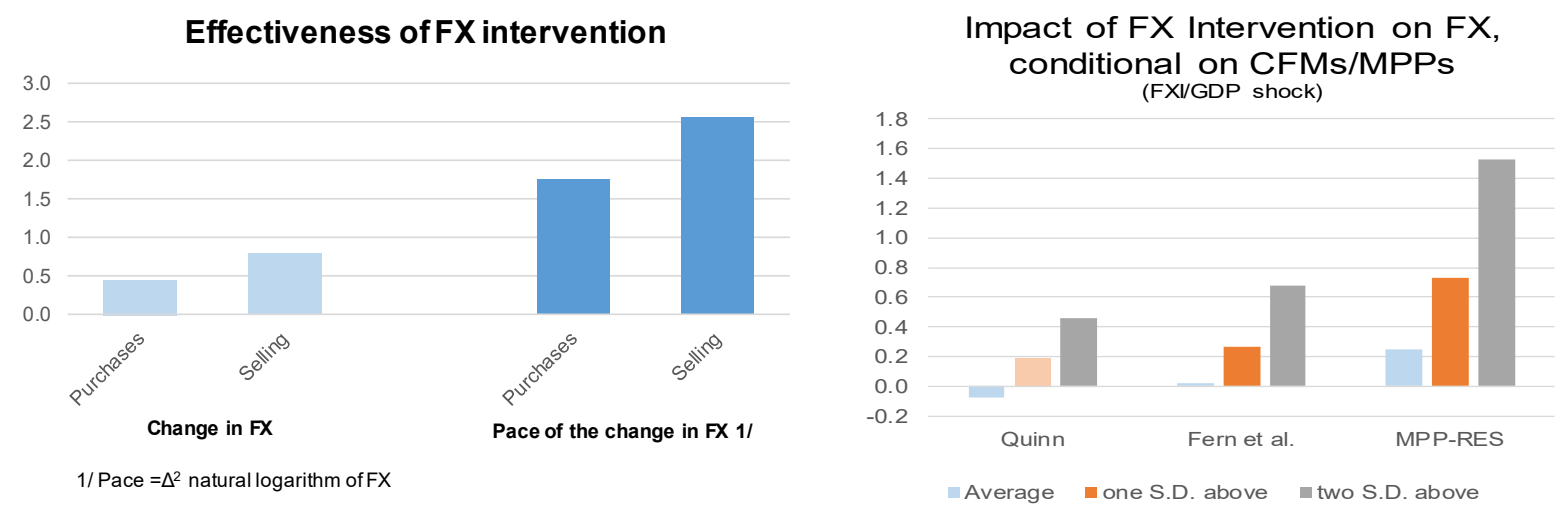

Sources: Quinn (1997), and Fernández et al (2015) for CFMs; Cerutti et al. (2015) for MPMs, IMF IFS for FX Reserves, and Authors' Calculations.

While experience is more limited, recent non-spot FXI seems similarly effective. Non-spot intervention may be different in character than spot FXI, but its impact on the exchange rate can be similar. Non-spot intervention does not directly affect the balance of demand and supply in the FX market, but can indirectly affect the demand for foreign currency by providing cover against the risk from the position held by private agents. If it is effective, non-spot intervention is likely to work through the same channels - portfolio and signaling — as spot FX intervention. There is limited experience with non-spot intervention. ${ }^{24}$

While the exchange rate significantly affects growth and inflation (Figure III.3), developments in credit growth are also important for NRE growth and inflation. Inflation and real economic conditions respond strongly to credit growth (Figure III.4), which may explain why quantity-based tools such as reserve requirements have traditionally been used by many NREs. This finding also

\footnotetext{
${ }^{24}$ Nedeljkovic and Saborowski (2017) find spot and non-spot intervention to be similarly effective in the case of Brazil. The analysis employs a common empirical framework, comparing the Brazilian Central Bank's (BCB) FX intervention in the spot markets with that using non-deliverable futures contracts. The BCB has used both these tools jointly to address foreign exchange pressure. The paper finds a significant link between intervention (in both spot and derivative sates markets) and changes in the Real/Dollar exchange rate. They also find that both spot and non-spot FXI are effective in affecting implied exchange rate volatility.
} 
suggests that policies such as MPMs, which affect the incentives for risk taking and borrowing, can influence the business cycle.

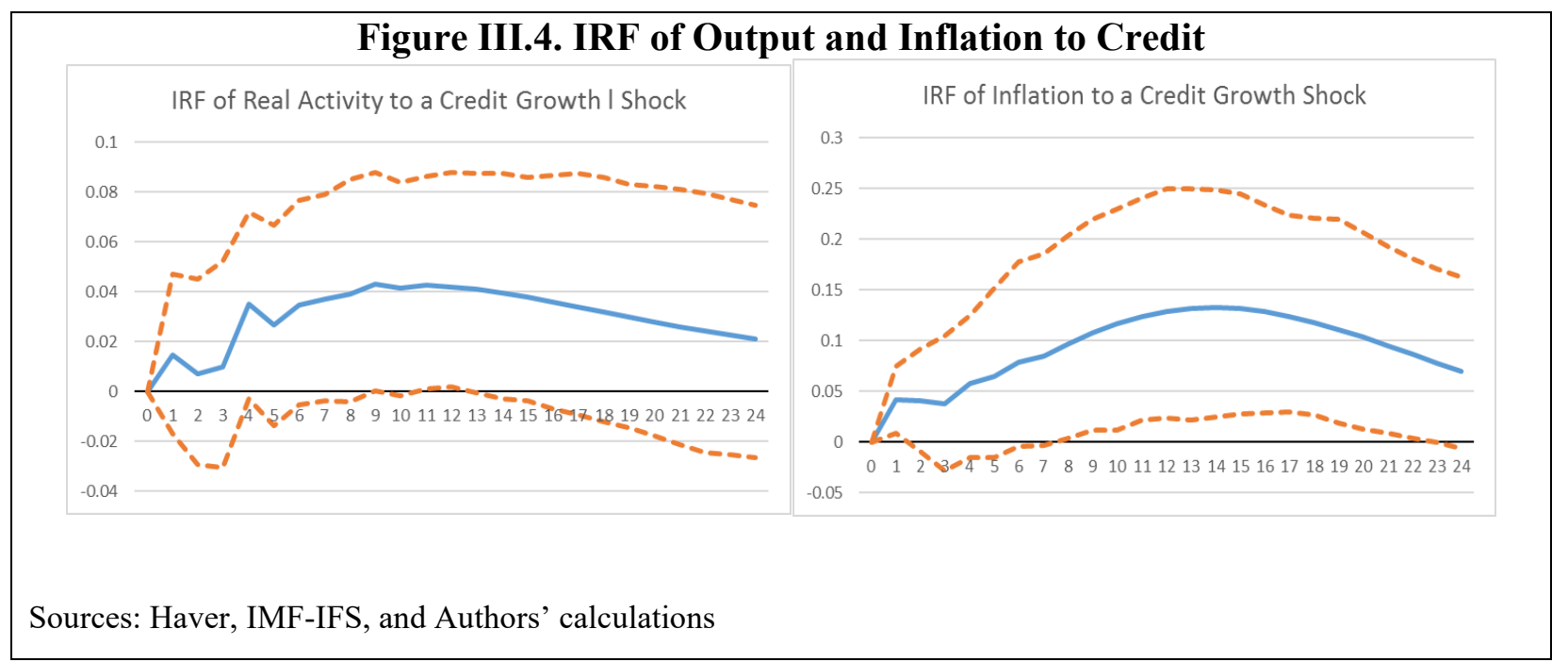

How monetary frameworks have been quantitatively affected by the use of macroprudential instruments and capital controls is something on which so far only country case studies have concretely focused (Nier et. al., 2012; Bruno, Shim, and Shin, 2017; Balog et al., 2015). To extend this analysis, we use panel regression analysis, we find that there are important interactions between the monetary policy response and the use of other policies, such as FXI, in NREs (Figure III.5). ${ }^{25}$ Specifically, an analysis of augmented Taylor rules for a sample of 79 countries, of which 49 emerging markets and developing countries, over 2000-2013 suggests that central banks react to financial sector stability and exchange rate concerns, as measured by changes in credit growth and NEER that are not explained by macroeconomic developments-i.e., credit and exchange rate gaps. ${ }^{26}$ However, a tightening of MPMs significantly lowers the reaction of policy rates to the credit gap. Similarly, a tightening of measures on capital inflows or outflows, or use of FXI, reduces the monetary policy reaction to an exchange rate gap (absent such measures, monetary policy rates tend to loosen in response to a positive gap, i.e. an exchange rate appreciation that is not explained by macroeconomic developments). The results are qualitatively similar when only emerging markets are included in the estimation, although the extent to which use of MPMs,

\footnotetext{
25 "Augmented Taylor rules" account for a broader set of central bank considerations, such as financial stability or exchange rate movements unexplained by fundamentals (see Käfer 2014 and references therein). To assess central banks' reactions to these variables one needs to deal with the endogeneity issue as, for instance, financial variables and exchange rates might both be affected by macroeconomic fluctuations and monetary policy decisions. Typical solutions usually include the use of real-time data and instrumental variable techniques with lagged terms of financial, exchange rate, macroeconomic variables, and policy rates.

${ }^{26}$ The variables are chosen specifically to test to what extent NREs' monetary policy stance can be explained by financial stability or external concerns. In particular, the propensity of monetary policy to react to credit considerations in certain circumstances has been termed "leaning against the wind" (IMF, 2015b). For the exchange rate, in the case of IT countries, the central bank only reacts to exchange rate volatility that threatens the inflation target rather than for the purpose of stabilizing the exchange rate.
} 
CFMs, or FXI affects the monetary policy reaction for EMs seems somewhat less than for the full sample. 


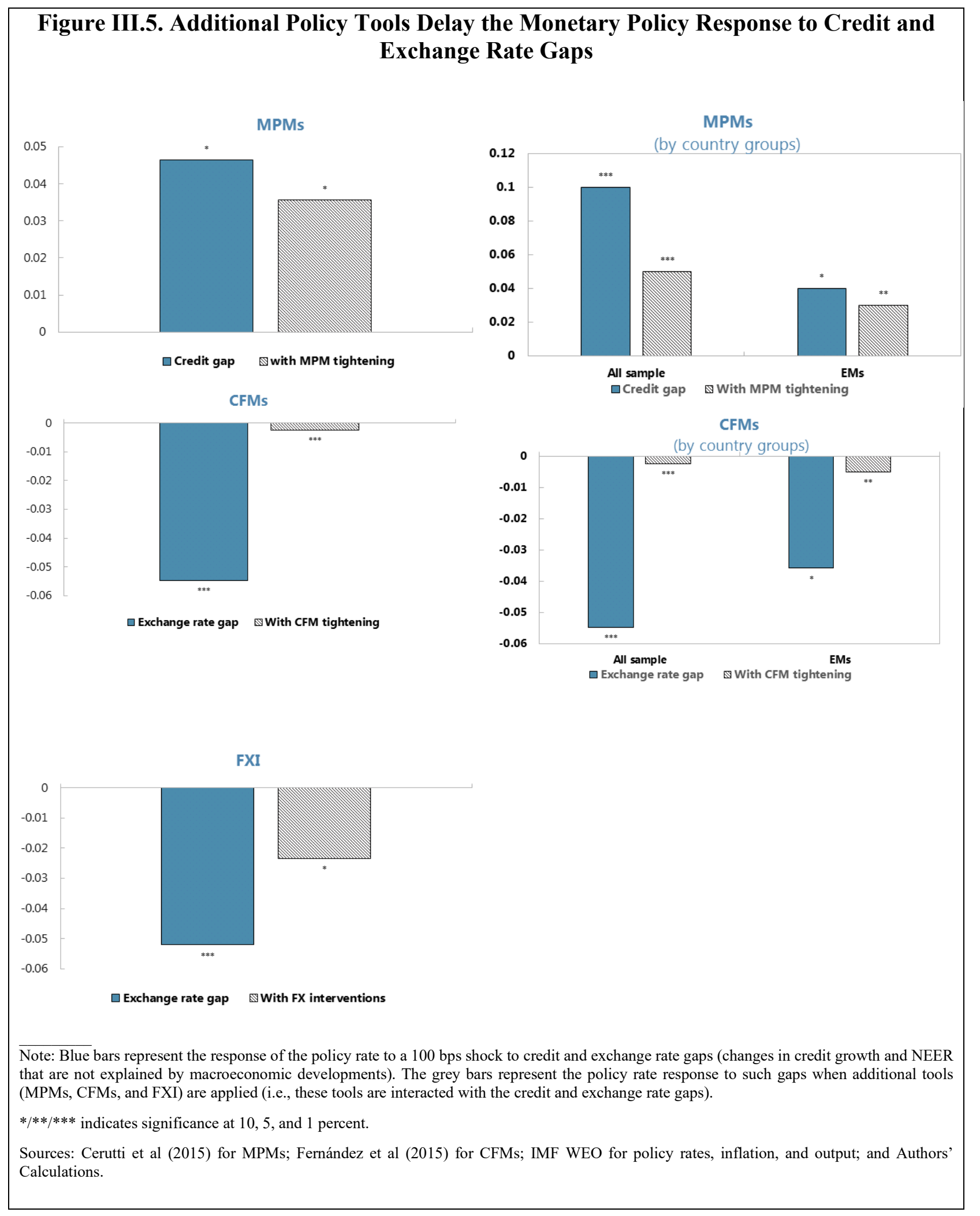




\section{Interest Rate Policy under Extreme External Pressure and FX Market Liquidity}

The experience of Russia in 2014 provides an interesting case study of the use of monetary policy through the interest rate to restore exchange market functioning. In 2014, Russia faced two adverse shocks: a drop in oil price and a sudden closure of access to international capital markets due to the sanctions imposed by some countries. These shocks resulted in significant market turbulence, large net capital outflows, significant currency depreciation-95 percent over the course of the year-and related inflationary pressures, with elevated concerns for financial stability. Given the restricted access Russian banks and companies had to external markets, there was significant strain in the FX market.

On December 16, 2014 the Central Bank of Russia (CBR announced a significant policy tightening - raising the policy rate by 650 basis points to anchor inflation expectations including by reducing depreciation expectations and mitigating the pass-through effects on inflation. ${ }^{27}$ While liquidity conditions in the FX market tightened upon the policy announcement, they soon after began to normalize (Box III.1). In addition to the policy rate change, the outcome was supported by other complementary measures aimed at supporting the stability of the financial system and expanding FX liquidity provision to banks, which helped ease funding pressures in the FX interbank market. The former included temporary forbearance measures on loan classification, provisioning, and valuation accounting. The later comprised the expansion of the collateral acceptable for FX repo auctions and the temporary easing of restrictions in banks' lending and deposit interest rates. The key policy rate was lowered by 200 basis points on January 31, 2015, and by July 2015 the interest rate was back to the level prior to the December 16, 2014 hike.

\footnotetext{
${ }^{27}$ Effective November 10, 2014 the CBR eliminated its exchange rate corridor and canceled regular foreign exchange interventions, adopted a de jure floating exchange rate regime (previously a de jure other managed).
} 


\section{Box III.1. The Impact of Interest Rate Policy in the Face of External Pressures}

Facing external pressures the Central Bank of Russia (CBR) introduced a significant change in interest rate policy in late-2014. In an unscheduled meeting early on December 16, 2014, the CBR decided on a dramatic policy rate hike of 650 basis points (moving to policy rate to 17 percent) as a critical component of a comprehensive package to confront a strong external pressure. ${ }^{28}$ The interest rate hike - the sixth hike in 2014-followed a $100 \mathrm{bps}$ increase in interest rates on December 11 and the introduction of repo transactions to "normalize the situation with foreign exchange liquidity.." ${ }^{29}$ Nonetheless, the ruble depreciated following the policy announcement and triggered a significant tightening of liquidity conditions in the FX market.

- Trading volumes increased substantially following CBR's interest rate hike.

- Liquidity conditions tightened as the market became one-sided amid rumors of possible introduction of capital controls and political criticism against the CBR. Bid-ask spreads increased by more than 617 percent relative to their average level during the week prior to the CBR's announcement. The effective cost of transactions increased by 640 percent over the same period and liquidity strains remained in place for a few days before normalizing.

- The impact of trading on the price (exchange rate) increased. The impact of order flows on the exchange rate returns increased significantly following the CBR's interest rate hike and remained high before normalizing the week after the policy event. This suggests that the market struggled to deal with larger transaction volumes. The return reversal—i.e., the speed with which the exchange rate return converges to fundamentals - recovered to its normal dynamics (as indicated by the negative coefficient in Table V.1).

\section{Table III.2. Liquidity Conditions in the FX Market Around the December 16, 2014 Hike} in the Key Policy Rate

\begin{tabular}{|lccccc||}
\hline & $\begin{array}{c}\text { Week before } \\
\text { Dec. 16 }\end{array}$ & Dec. 16 & Dec. 17 & $\begin{array}{c}\text { Week after } \\
\text { Dec. 17 }\end{array}$ & $\begin{array}{c}\text { Memo: Full } \\
\text { Sample }\end{array}$ \\
\hline Bid-Ask Spread (bps) & 14.38 & 88.85 & 242.91 & 64.44 & 10.03 \\
Effective cost of & 1.65 & 10.56 & 14.44 & 14.60 & 1.06 \\
transaction (bps) & 2.50 & 13.56 & 13.56 & -0.42 & 0.80 \\
Price Impact (bps) & 4.29 & -3.63 & -21.76 & -12.61 & 0.42 \\
& 89.01 & 130.82 & 72.59 & 36.78 & 101.95 \\
Traded Volume (index) & \multicolumn{5}{l}{} \\
\hline
\end{tabular}

\footnotetext{
${ }^{28}$ CBR also announced that it intended to introduce in the "near future" foreign exchange lending secured by non-marketable assets. These complementary measures were implemented on December 18 .

${ }^{29}$ On November 10 CBR abolished the dual currency soft peg along with its automatic interventions-putting an end two decades of exchange rate controls. With this decision CBR began to intervene in the market to address "financial stability threats" and moved the FX regime closer to a free float.
} 


\section{The Impact and Effectiveness of Policy Packages}

This section applies models ${ }^{30}$ of small open NREs to illustrate the impact of alternative policy responses using an expanded toolset. Key conclusions are that the effectiveness of a policy package is highly dependent on the type of shock and constraints on monetary policy transmission such as the effective lower bound (ELB).

The analysis builds on the findings in the preceding discussion, which has established that (i) monetary policy can transmit through long-term interest rates; (ii) exchange rate flexibility plays a critical role as a buffer ${ }^{31}$; (iii) the credit channel remains effective in many NREs; and (iv) there are important interactions between policy instruments which affect the impact of an overall package. The discussion compares a policy package with a simpler policy response relying on monetary policy and complete exchange rate flexibility. In part 1, the additional tools of FXI and CFMs are discussed. In part 2, the effectiveness of a policy package of monetary policy with MPMs aimed at reducing systemic risks from foreign currency loans is discussed including in the case of the lower bound constraint on monetary policy.

\section{Monetary Policy, FXI, and the Impact of CFMs}

This section outlines the impact of different combinations of interest rate policy and FXI on the effectiveness of policy in smoothing the impact of external financial and domestic demand shocks. In addition, it argues that the existence of CFMs would reduce the monetary policy and FXI response. This discussion uses a stylized New Keynesian small open economy model.

In the stylized set-up, based on Escudé (2013), the central bank is assumed to manage monetary policy through a relatively standard Taylor rule, and also to manage an intervention rule in order to stabilize the exchange rate in the face of shocks. We compare two policy regimes: a pure float where the central bank follows only its Taylor rule; and a policy using a combination of interest rate policy based on a Taylor rule and FX intervention, a so-called managed float regime. Two temporary macroeconomic shocks are considered: (i) an external financial conditions shock (modeled as a risk premium shock); ${ }^{32}$ and (ii) a domestic demand shock. As elaborated in Annex I, other domestic shocks, like a supply shock, yield qualitatively similar results.

- Tighter external financial conditions shock. The introduction of exchange rate management via FXI ensures the interest rate is less responsive to a rise in the cost of foreign funds (Figure III.6). That is, without FXI, a rise in the risk premium leads to a currency depreciation, which via import prices results in higher CPI inflation and leads the central bank to raise policy rates. Under the regime with the two policy tools, FXI reduces the rate of depreciation and hence lowers the impact on inflation. This then results in a lower domestic rate hike to achieve

\footnotetext{
${ }^{30}$ Since the models used in the section are highly stylized intending to characterize interactions between FX intervention/MPPs and monetary policy instruments, the results do not fully reflect the effect should FXI create distortions or domestic financial intermediation suffer from significant frictions. Because the models are calibrated to small open economies, their results are less applicable to more closed NREs, accounting also differences between the models' results and the empirical evidence in Section II. ${ }^{31}$ Of course, there are costs related to FX intervention like sterilization costs. However, this paper does not explicitly discuss this issue in order to focus on the interaction between FX intervention/MPPs and monetary policy instruments. Calibrating appropriate policy mix including fiscal would definitely need to count such costs.

${ }^{32}$ Given interest rate parity, the risk premium shock is equivalent to a rise in foreign interest rates.
} 
domestic inflation, output and employment objectives. Consequently, FX intervention can help manage extreme external pressure, especially if the country has substantial exchange rate passthrough or currency mismatches (that would exacerbate balance sheet risks following currency depreciation).

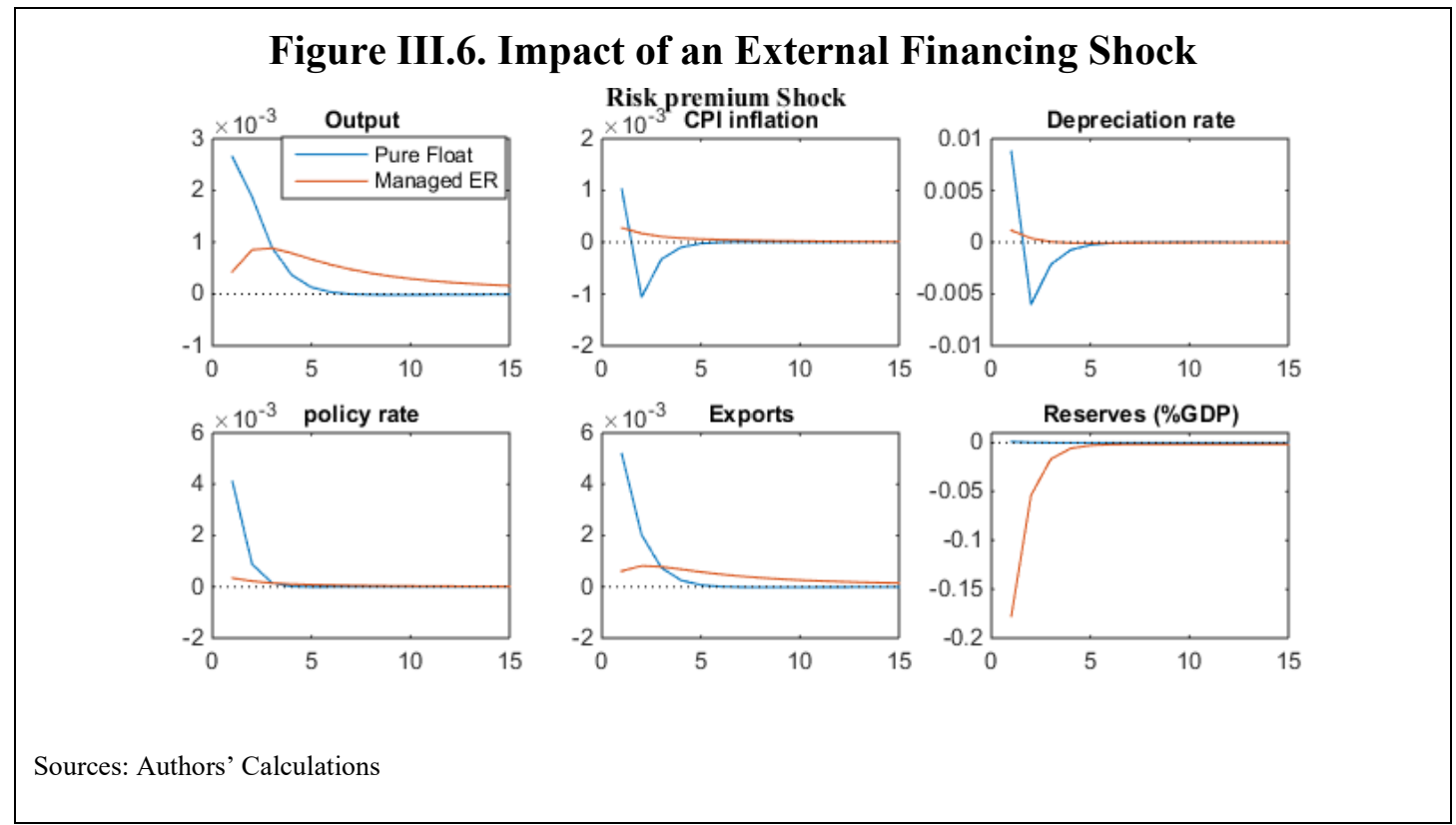

- Domestic demand shock. FX intervention tends to shorten the duration of higher inflation and the required policy rate hike in response to the domestic demand shock (Figure III.7). There is little difference across the two policy regimes right after the shock as they both result in higher inflation and policy rates. However, subsequently FXI limits the extent of exchange rate depreciation and keeps inflation and policy rates somewhat lower than when FXI is not used, at the cost of a more prolonged current account deficit and lower output. As such, the smoothing effect of FXI is significantly lower in the face of a domestic demand shock compared with the external financing shock.

- Overall, the combined use of monetary policy and FXI tends to smooth the impact of the shock on the domestic economy. However, the degree of smoothing crucially depends on the nature of shock. The use of FXI has a far greater impact on economic developments for an external financing shock than in the case of the demand shock. This is because FXI can directly mitigate the external financing shocks given interest rate parity, insulating domestic interest rates. 


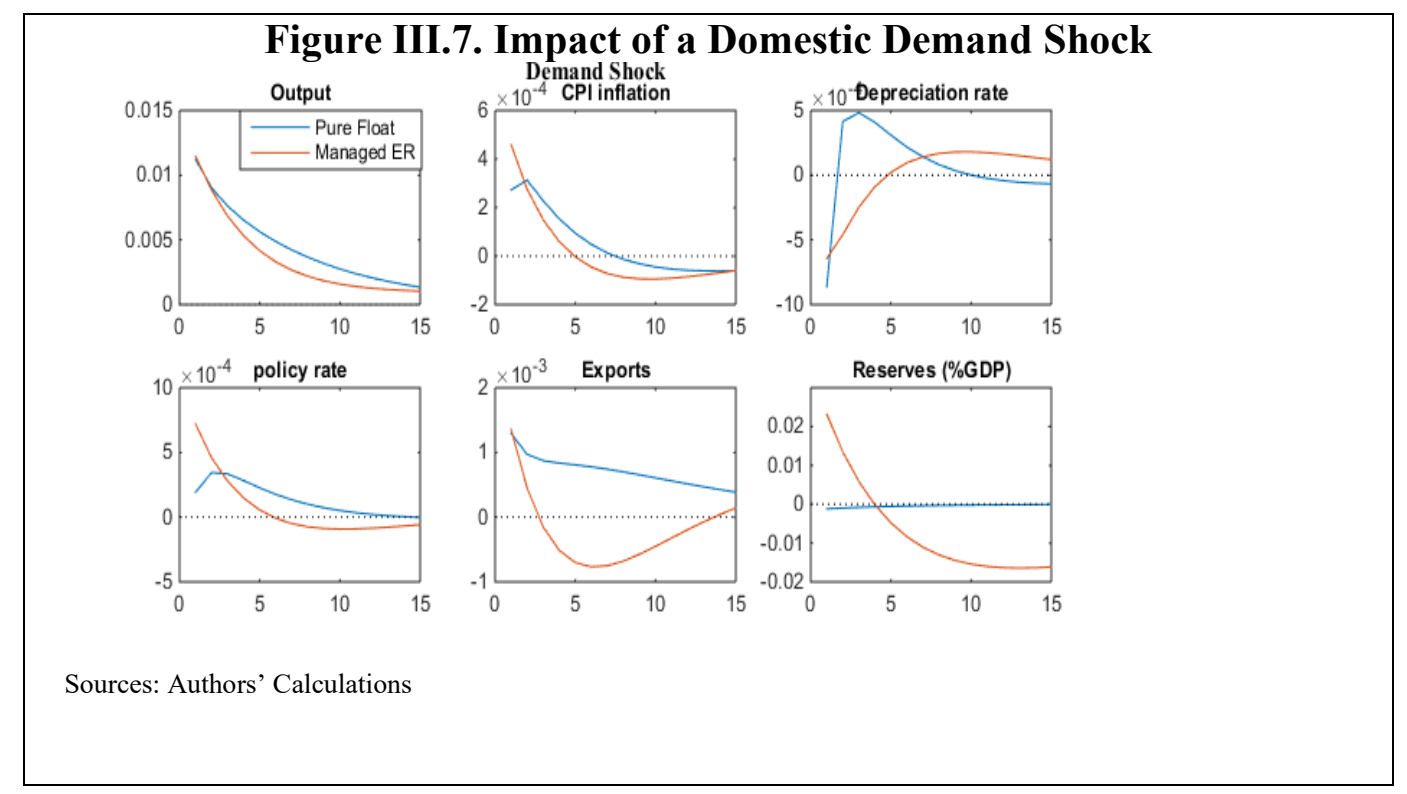

The combination of FXI and interest rate policy also alters the trade-offs policymakers face (Figure III.8). The monetary policy frontiers between output and inflation volatility show the best (lowest variance) combination of inflation and output variability obtainable given alternative weights in the policy rules. ${ }^{33}$ That is, for different central bank preferences over inflation and output volatility, it shows the best possible outcome. For external financing shocks, the two-policy regime is superior to a pure float with Taylor rule in the sense that the obtainable output and inflation volatility is generally preferable to that available under a pure float. This suggests that a combination of FX intervention and interest rate policy could achieve lower output and inflation volatility in response to external pressures than a single-instrument response. For domestic demand shocks, the central bank faces a trade-off between inflation and output-gap stabilization, as implied by the negative slope of the frontiers.

\footnotetext{
${ }^{33}$ Specifically, policy frontiers are derived by altering the Taylor coefficient parameters on output and inflation and looking at the simulated volatility of inflation and output for each set of parameters looking at each shock in isolation.
} 


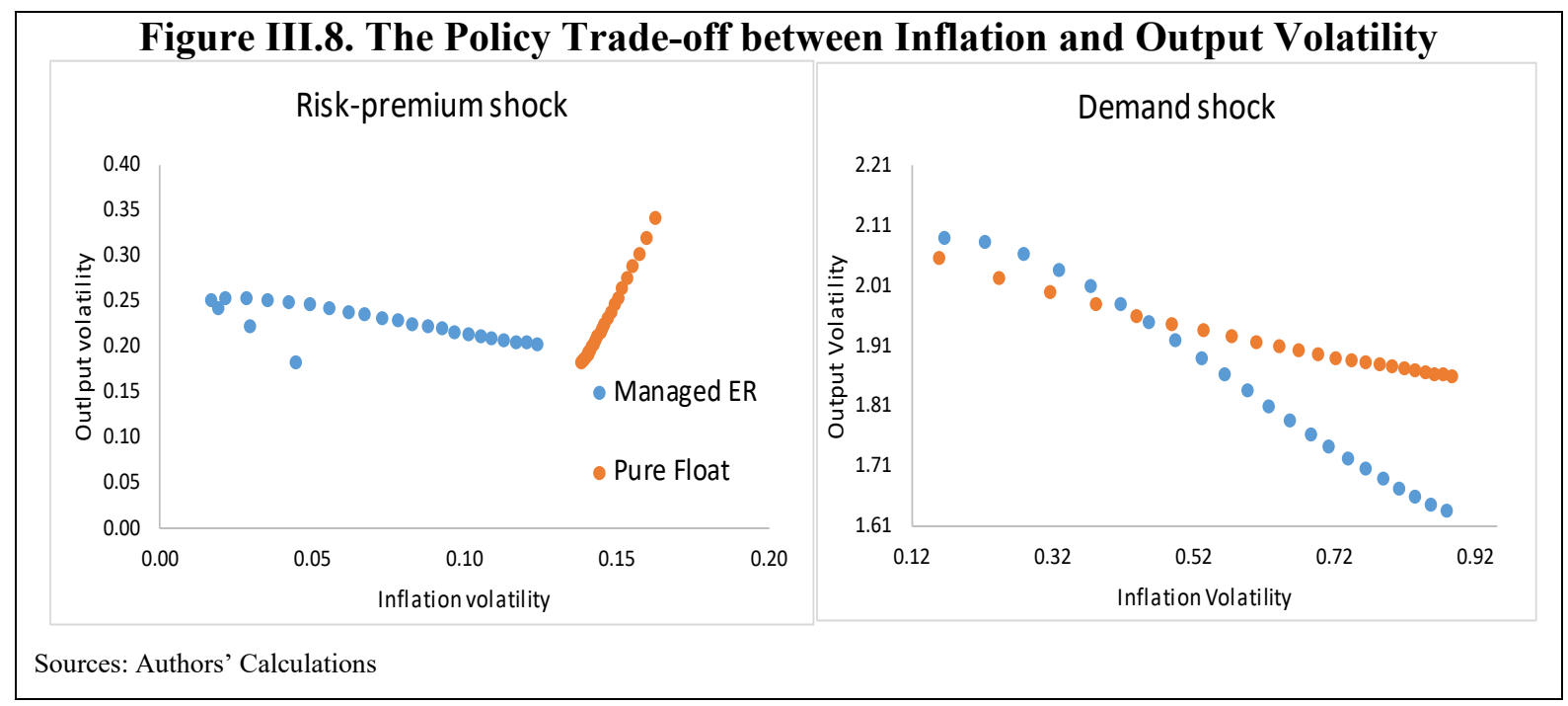

Based on the discussion in previous sections, the existence of CFMs would likely result in a smaller response through interest rate policy and FX intervention. In particular, CFMs limit the extent of capital flows for any given external shock and their response to any interest rate movement. They also enhance the effectiveness of intervention (as discussed in in section III.B). Thus, the impact of the external financial conditions shock would be smaller, and the response of policy rates and the amount of FXI would also be smaller than in the absence of CFMs. Given the more limited effect of FXI for the demand shock, the CFMs would mitigate the exchange rate impact, but not really change the main elements of the policy package.

\section{Monetary, Fiscal, and Macroprudential Policies, when Monetary Policy is Constrained}

In this section, we study the interaction between monetary, fiscal, and macroprudential policies in response to external shocks. We find that using a combination of policies-for example, having a macroprudential policy targeted at foreign borrowing - enhances the effectiveness of the overall policy response, which can ease constraints on monetary policy relevant for NREs facing an effective lower bound on policy rates.

Open-economy dynamic stochastic general equilibrium (DSGE) models addressing interactions between monetary policy and various policy tools to manage external shocks are still limited in number. Moreover, most open-economy models do not consider the case when monetary policy is constrained, for example, by a lower bound. Chen and Laseen (2017) develop a novel openeconomy DSGE model to investigate how interactions between monetary, fiscal, and certain macroprudential policies, in the context of high foreign currency borrowing, affect the central bank's ability to achieve its inflation target. ${ }^{34}$

\footnotetext{
${ }^{34}$ Specifically, the lower bound constraints faced by some advanced NREs — and possibly some financially-integrated EMs — are modeled as an exogenous constraint (fixed level of interest rate) below which the monetary authority cannot lower policy rates. The model considers the special case of the lower bound fixed at zero (which is relevant for advanced NREs but not for most EMs). EM central banks, however, may take as an "interim" lower bound a positive level of interest rate under some circumstances (e.g., fear of capital outflows). If the constraint were a small positive number, we would not expect the results to change qualitatively. A more
} 
The analysis considers two additional policy tools in addition to monetary policy and assumes a fully flexible exchange rate. A fiscal authority can raise taxes to finance its expenditures.

Moreover, a macroprudential authority can set a variable levy on foreign borrowing to mitigate systemic financial sector risks from the build-up of excessive foreign currency exposures. ${ }^{35}$

The model results suggest that, in general, having a macroprudential policy instrument is more beneficial than a single instrument (interest rate) response. As illustrated in Figures III.9a, in the event of a global supply shock that lowers inflation, the monetary policy responses raise inflation faster when the macroprudential instrument is activated to maintain financial stability (blue lines) than in its absence (black lines). The policy interest rate does not need to be lowered as much where macroprudential policy is activated. The main channel through which the macroprudential policy helps to raise inflation faster is the exchange rate depreciation (lower left panel in Figure III.9a). In response to the global supply shock, a levy on firms' borrowing is increased inducing firms to further reduce the foreign credit (lower right panel), which, as a result, weakens the appreciation pressure caused by the shock. Fiscal policy in combination with monetary policy also helps to raise inflation faster (red dotted line,) but its transmission channel is different.

The results also suggest that the gain from having a macroprudential policy as an additional instrument is significantly larger when monetary policy is constrained. Figure III.9b shows that, when monetary policy is constrained by the ELB, a macroprudential policy instrument as considered in the previous paragraph helps to raise inflation much faster toward the target, in turn allowing the policy rate to leave the lower bound earlier. The figures also point to higher fiscal multipliers at the ELB, in line with previous studies' findings.

The macroprudential policy reduces the externality generated by the ELB. As monetary policy hits the ELB, domestic bank credit becomes relatively more expensive compared with the foreign credit. Thus, firms choose to borrow relatively more abroad (this is shown as foreign borrowing falling less in the baseline when monetary policy is constrained (Figure III.9b) compared with when it is unconstrained (Figure III.9a). This generates an externality in that higher capital inflows create additional appreciation pressure, which the firms do not internalize. Macroprudential policy in the model, which is designed to limit the build-up of systemic risk, could reduce this externality by making foreign credit more expensive relative to domestic funding. Hence, firms would borrow less in international markets reducing the appreciation pressure resulting from the lower bound on interest rates. ${ }^{36}$ Fiscal policy, on the other hand, carries a larger multiplier because the nominal interest rate is not raised ("fixed" at the ELB) in response to an increase in government spending.

complicated case where the constraint is endogenous (e.g., related to the level of external debt) would be a possible direction for future work.

${ }^{35}$ This policy measure can be considered to be a CFM as well as an MPM.

${ }^{36}$ Interestingly, this effect is similar to the one discussed by Jeanne and Svensson (2007) and Eggertsson (2006). If the government prints nominal liabilities (such as government bonds or money) and purchases foreign exchange, it will incur balance-sheet losses if it reneges on an inflation promise because this would imply an exchange rate appreciation and thus a portfolio loss. 


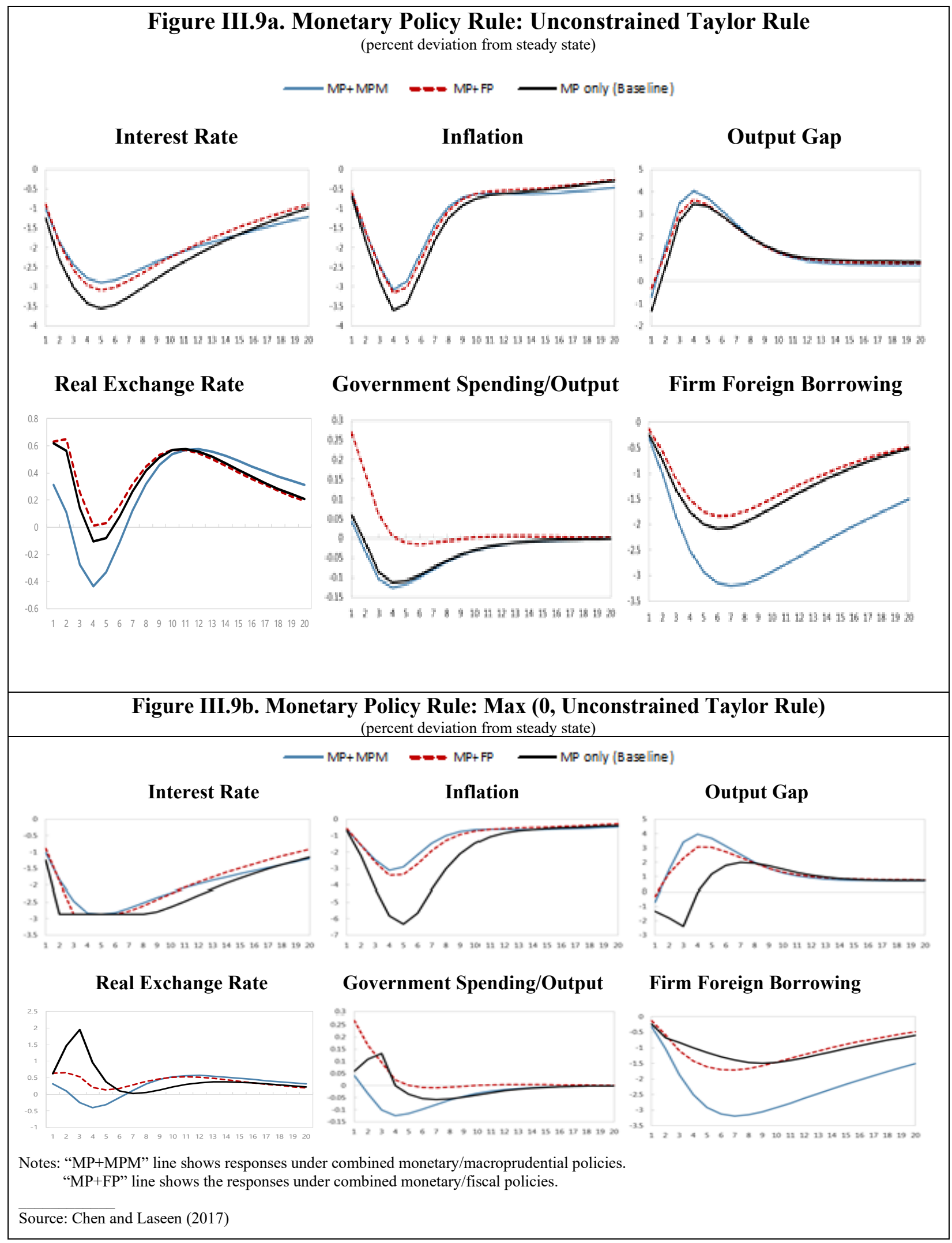




\section{CONCLUSION}

NREs have broadened their policy toolkit to allow greater exchange rate flexibility while including MPMs, FXI and, to a more limited degree, CFMs over the past 15 years. In response to the COVID-19 related shocks, EMs in particular have allowed the exchange rate to play a large shock absorber role while the use of CFMs has been limited so far. The wider use of these toolsincluding among AEs after the GFC - has in turn led to growing awareness that policy interactions matter. A substantial literature, so far comprising mostly theoretical models and country case studies, has studied the impact of policy interactions but not directly measured their extent in practice. To help fill this gap, this paper provides both direct measures of the quantitative implications of policy interactions for monetary policy independence, monetary policy response, and FXI effectiveness and an assessment of the policy mix effectiveness and its transmission. A more complete analysis would require the establishment of benchmarks for assessing effectiveness of different policy combinations.

The results confirm that growing financial integration makes NREs susceptible to global financial spillovers. In particular, we find that external real and financial shocks affect domestic real and financial conditions, policy transmission to long-term rates, and the monetary policy reaction. The dependence of monetary policy on international monetary policy spillovers and its response to non-traditional objectives (external and financial stability) is attenuated significantly in countries which use FXI and/or activate other tools (MPMs and CFMs). We also find that FXI can reduce exchange rate volatility and is more effective with CFMs under some circumstances.

Our findings finally suggest that a policy response that relies on a combination of instruments can sometimes be more effective than a single instrument response. A model-based analysis suggests that the relative effectiveness of a combined monetary policy response with FXI to external pressures is highly dependent on the nature of the shocks. FXI can help smooth the impact of external financing shocks, but adds relatively little to the response to domestic demand (or supply) shocks. In the case of a global disinflationary shock, the results from a stylized model suggest that well-targeted MPMs combined with monetary policy are more effective at stabilizing inflation and output than monetary policy alone, particularly when monetary policy faces constraints such as a ZLB.

It would be important to explore the effectiveness of alternative policies in softening the monetary policy response to other types of global financial shocks besides US monetary policy shocks. Other interactions between instruments used by NREs to stabilize their economies in the face of shocks could also be explored. Examples include the interaction between CFMs/MPMs, FXI/MPMs, and the nexus between fiscal policy and unconventional tools (including UMP recently deployed by some EMs to address market dysfunction from COVID shock). Lastly, a more granular examination should be applied in individual country cases given the specifics of policy transmission and shocks affecting the economy (see Fayad and Poirson, 2020). This would be required to translate the high-level approach taken in this paper into practical policy application at the country level. 


\section{Annex I. Monetary Policy, FXI, and the Impact of CFMs}

This section aims at investigating the economic theory behind various monetary policy regimes and evaluating the implications of policy design in managing the cycle. The key question that this section addresses is to explicitly account for an intervention policy by the $\mathrm{CB}$ and to what degree the augmentation of the interest-rate setting rule with exchange rate management can in fact lead to better policy outcomes. Below we draw heavily on the model by Escude (2013).

\section{Model overview}

The model closely follows a standard new Keynesian small open economy model as outlined in Escude (2013) using the Dynare code provided by the author. Households consume both domestic and imported goods as well as hold financial wealth in the form of domestic bonds issued by the $\mathrm{CB}$ as well as can borrow from abroad by issuing foreign currency bonds. In this sense the asset market structure in incomplete. The rate at which households can borrow in the international markets consists of the international risk free rate $i^{*}$ augmented by an endogenous risk premium which depends on the aggregate debt to GDP ratio (SchmidtGrohe and Uribe 2003). Production is carried out by firms producing domestic goods as well as exports. Price setting is staggered ala Calvo (1983) and the export good is envisaged to be primary good (commodity). The central bank issues currency, domestic currency bonds as well as holds international reserves (r) in the form of foreign currency denominate risk free bonds issued by the rest of the world.

\section{i. $\quad$ Modelling Risk Premium}

The rate at which residents borrow in the international markets is defined by:

$$
1+i_{t}^{D}=\left(1+i_{t}^{*}\right) \phi^{*} \tau_{D}\left(\frac{S_{t} D_{t}}{P_{t} Y_{t}}\right)
$$

Where $S_{t}$ is the nominal exchange rate (domestic/foreign currency), $D_{t}$ is foreign debt, $P_{t} Y_{t}$ is the nominal GDP, $\phi^{*}$ is an exogenous stochastic component that can capture shocks to

international liquidity and $\tau_{D}\left(\frac{S_{t} D_{t}}{P_{t} Y_{t}}\right)$ is the gross risk premium which is an increasing function of the foreign debt to GDP ratio. This captures the idea of a debt-elastic interest rate (Schmitt-Grohe and Uribe, 2003) which ensure stationarity in the model.

\section{ii. $\quad$ Monetary Policy}

The central bank issues currency $M_{t}$ which is held by households to lower transaction costs, issues domestic currency bonds $B_{t}$ as well as holds international reserves $\left(R_{t}\right)$ in the form of foreign currency denominated risk free bonds issued by the rest of the world. Any profits related to interest earned and capital gains from holding reserves are assumed to be transferred to the government every period (Adler and Medina 2016), making central banks' net worth constant. Flow budget constraint of the $\mathrm{CB}$ is

$$
M_{t}+B_{t}-S_{t} R_{t}=M_{t-1}+\left(1+i_{t-1}\right) B_{t-1}-\left(1+i_{t-1}^{*}\right) S_{t} R_{t-1}
$$




$$
=M_{t-1}+B_{t-1}-S_{t-1} R_{t-1}-q u a s i_{-} \text {fiscal }
$$

Where quasi-fiscal refers to the interest income and capital gains form FX reserves assumed to be transferred to the government every period. The CB balance at each period can therefore be stated as $M_{t}+B_{t}-S_{t} R_{t}=0$ which can be interpreted as the CB constraint and dictates the sterilization of FX intervention. ${ }^{37}$

a. Taylor Rule

$$
\frac{1+i_{t}}{1+i}=\left(\frac{1+i_{t-1}}{1+i}\right)^{h 0}\left(\frac{\pi_{t}}{\pi^{T}}\right)^{h 1}\left(\frac{Y_{t}}{Y}\right)^{h 2}\left(\frac{e_{t}}{e}\right)^{h 3}
$$

Where $h 0$ captures the inertia of setting interest rates not to different from last period's and $h 1, h 2$ and $h 3$ capture the weight placed in minimizing deviations from the target inflation, steady state output and real exchange rate respectively. ${ }^{38}$

\section{b. Intervention policy}

Here a second operational target is introduced, that of the rate of nominal depreciation, whose instrument is the buying/selling of FX reserves by the CB. While this operational target can also respond to the same variables as the Taylor rule, in the baseline we assume $k 0=k 1=k 2=k 3=0$. The coefficient on foreign reserves $k 4$ is negative - an increase in international reserves lowers the rate of deprecation and vice versa.

$$
\frac{\delta_{t}}{\delta}=\left(\frac{\delta_{t-1}}{\delta}\right)^{k 0}\left(\frac{\pi_{t}}{\pi^{T}}\right)^{k 1}\left(\frac{Y_{t}}{Y}\right)^{k 2}\left(\frac{e_{t}}{e}\right)^{k 3}\left(\frac{e_{t} r_{t} Y_{t}}{e r / Y}\right)^{k 4}
$$

where $\delta$ is the nominal depreciation rate and $r$ is the stock of $\mathrm{FX}$ reserves.

In the benchmark simulations we try to show how the introduction of a second rule alters the response to different shocks and what it implies for the volatility trade-offs between CPI inflation and output as we alter the policy parameters. For the benchmark results in section IV the following parameters are used: $h 0=0.2$;

$h 1=1.2 ; h 2=0.02 ; h 3=0 ; k 0=k 1=k 2=k 3=0 ; k 4=-0.005$

37 This is a stylized assumption to simplify notation. Some central banks transfer such amounts annually rather than each period. Our assumption does not impact on the model's economic results provided the amounts are saved and sterilized until they are transferred. Assuming that the CB is reimbursed for its capital losses ignores a main concern about sterilized FXI which is the cost of carry in case the return on reserves is lower that the local interest rate on bonds, or in case the exchange rate (S) appreciates and drags the CB to a negative capital position. This quasi-fiscal cost reflects the price of FX purchases as a shield against appreciation pressures. In practice, the level of reserves is likely to influence FXI decisions beyond a certain threshold (Section III.B and footnote 20). This threshold is not considered in the model.

${ }^{38}$ The Taylor rule specification is used to mimic the actually observed behaviors of monetary policy. This does not necessarily mean that the central bank attempts to stabilize the exchange rate (ex ante). IT central banks will only react to exchange rate volatility that threatens the inflation target. 


\section{iii. $\quad$ Optimal Simples Rules}

The central bank is assumed to minimize a simple quadratic loss function (), which is a weighted sum of the volatility of output, inflation, interest rate changes as well as changes in the rate of depreciation. Under the pure float regime, the optimal simple rule implies choosing parameters $h 0, h 1, h 2$ and $h 3$ of the Taylor rule above. Under the managed float regime instead this implies choosing $h 0, h 1, h 2$ of the Taylor rule and $k 4$ of the Intervention rule. We note that for simplicity we are focusing on the type of intervention policy that targets the rate of depreciation and where $k 1, k 2, k 3=0$.

$$
\text { Loss }=w_{\pi} \operatorname{Var}(\pi)+w_{y} \operatorname{Var}(y)+w_{\Delta i}(\Delta i)+w_{\Delta \delta} \operatorname{Var}(\Delta \delta)
$$

\section{References}

Adler, G., and C. Tovar, 2011, "Foreign Exchange Intervention: A Shield against Appreciation Winds?" IMF Working Paper 11/165.

Adrian, T., Erceg, J. C., Lindé, J., Zabczyk, P., Zhou, J., 2020, “A Quantitative Model for the Integrated Policy Framework" IMF Working Paper 20/122.

Agur, I., Mangal Goswami, Shinichi Nakabayashi, and Sunil Sharma, 2015, "Lessons for Frontier Economies from the Recent Experience of Emerging Markets" in Frontier and Developing Asia: The Next Generation of Emerging Markets, International Monetary Fund.

Akinci, O., and J. Olmstead-Rumsey, 2015, "How Effective Are Macroprudential Policies? An Empirical Investigation,” International Finance Discussion Papers 1136.

Aizenman, J., M.D. Chinn, and H. Ito, 2013. “The "Impossible Trinity” Hypothesis in an Era of Global Imbalances: Measurement and Testing," Review of International Economics, 21 (3), 447-458.

Arregui, N., S. Elekdag, R. G. Gelos, R. Lafarguette, D. Seneviratne, 2018, “Can Countries Manage Their Financial Conditions Amid Globalization?” IMF Working Paper 18/15.

Banbura, M., Giannone, D. and L. Reichlin, 2010, "Large Bayesian Vector Auto Regressions," Journal of Applied Econometrics, 25, 71-92.

Basu, S. E. Boz, G. Gopinath, F. Roch, and F. Unsal, 2020, “A Conceptual Model for the Integrated Policy Framework” IMF Working Paper 20/121, International Monetary Fund, Washington, DC.

Bernanke, B.S., Bovian, J., and P. Eliasz, 2005, "Measuring the Effects of Monetary Policy: a factorAugmented Vector Autoregressive (FAVAR) Approach," Quarterly Journal of Economics, 120, $387-422$.

Blanchard, O., Dell'Ariccia, G. and P. Mauro, 2013, "Rethinking Macro Policy II: Getting Granular,” IMF Staff Discussion Note, 13/03, April 2013. 
Brandao-Marques, L., G. Gelos, M. Narita, and N. Nier, 2020, "Leaning Against the Wind: An Empirical Cost-Benefit Analysis for an Integrated Policy Framework," IMF Working Paper 20/123.

Bruno, V., Shim, I., and H.S. Shin, 2017, "Comparative Assessment of Macroprudential Policies," Journal of Financial Stability, 28, 183-202.

Caselli, F.G., and A. Roitman, 2019, "Non-Linear Exchange Rate Pass-Through in Emerging Markets," Internaltional Finance, 22 (3), 279-306.

Cerutti, E., Claessens, S., and Laeven, L. ,2015, “The Use and Effectiveness of Macroprudential Policies: New Evidence,” IMF Working Paper 15/61.

Chen, J. and Laseen, S., 2017, " External Shocks and the Design of Macroprudential Policy at the Zero Lower Bound," Unpublished manuscript.

Chinn, M. D. and Ito, H., 2006, "What Matters for Financial Development? Capital Controls, Institutions, and Interactions," Journal of Development Economics, 81(1), 163-192.

Christiano, L., Eichenbaum, M., and Rebelo, S., 2011, "When Is the Government Spending Multiplier large?” Journal of Political Economy, 119(1), 78-121.

Coenen, G., C. J. Erceg, C. Freedman, D. Furceri, M. Kumhof, R. Lalonde, D. Laxton, J. Lindé, A. Mourougane, D. Muir, S. Mursula, C. de Resende, J. Roberts, W. Roeger, S. Snudden, M. Trabandt, and J. in't Veld, 2012, "Effects of Fiscal Stimulus in Structural Models," American Economic Journal: Macroeconomics, 4 (1), 22-68.Davig, Troy and Eric M. Leeper (2011), "Monetary-Fiscal Policy Interactions and Fiscal Stimulus," European Economic Review, 55(2), 211-227.

Eggertsson, G., 2006, “The Deflation Bias and Committing to being Irresponsible,” Journal of Money, Credit and Banking, 36 (2).

, 2011, "What Fiscal Policy Is Effective at Zero Interest Rates?" NBER Macroeconomics Annual 2010, 59-112.

Erceg, C. and Lindé, J., 2014, "Is There a Fiscal Free Lunch in a Liquidity Trap?" Journal of the European Economic Association, 12(1), 73-107.

Escudé, G.J., 2013, “A DSGE Model for a SOE with Systematic Interest and Foreign Exchange Policies in Which Policymakers Exploit the Risk Premium for Stabilization Purposes," Economics: The Open-Access, Open-Assessment E-Journal, Vol. 7, 2013-30.

Fayad, G. and H. Poirson, 2020. "Caught in the Crosswinds: The Experiences of Small Open Economies Responding to External Volatility with Multiple Policy Levers ," IMF Working Paper 2020/225. 
Fernández, A., Klein, M.W., Rebucci, A., Schindler, M. and M. Uribe, 2015, “Capital Control Measures: A New Dataset," IMF Working Paper 15/80.

Finger, Harold, and P. L. Murphy, 2019, "Facing the Tides: Managing Capital Flows in Asia," Asia and Pacific Department Paper 19/17, International Monetary Fund, Washington, DC.

Frankel, J., Parsley, D., Wei, S.J., 2012, “Slow Pass-Through around the World: a New Import for Developing Countries? Open Economies Review, 23(2), 213-251.

Galati, Gabriele, and Richhild Moessner, 2013, "Macoprudential Policy—A Literature Review" Journal of Economic Surveys, 27(3), 846-878.

Gelos, G., L. Gornicka, R. Koepke, R. Sahay, and S. Sgherri. 2019. "Capital Flows at Risk: Taming the Ebbs and Flows," IMF Working Paper No. 19/279, International Monetary Fund, Washington, DC.

International Monetary Fund. 2012. "The Liberalization and Management of Capital Flows: An Institutional View," November 2012.

, 2013a, “Assessing Reserve Adequacy_Further Considerations."

, 2013b, "World Economic Outlook", October 2013.

, 2013c, "Guidance Note for the Liberalization and Management of Capital Flows."

, 2014, "Staff Guidance Note on Macroprudential Policy."

, 2015a, "Managing Capital Outflows - Further Operational Considerations."

, 2015b, “Monetary Policy and Financial Stability” Policy Paper, August 2015.

,2016, "Reference Note on Unconventional Monetary Policies and Foreign Exchange Intervention under Disorderly Market Conditions." (internal paper)

,2016, “Asean-5 Cluster Report—Evolution of Monetary Policy Frameworks,” June 2016.

,2017, “Are Countries Losing Control of Domestic Financial Conditions?” Chapter 3 in April 2017 GFSR.

Jeanne, O. and Svensson, L., 2007, "Credible commitment to optimal escape from a liquidity trap: the role of the balance sheet of an independent central bank," American Economic Review, 97, 474-90.

Jordà, Ò., 2005, “Estimation and Inference of Impulse Responses by Local Projections,” American Economic Review, 95 (1), 161-82.

Käfer, Benjamin, 2014, "The Taylor Rule and Financial Stability: A Literature Review with Application for the Eurozone," MAGKS Discussion Paper 30-2014. 
Kim, S., Roubini, N., 2000," Exchange Rate Anomalies in the Industrial Countries: a Solution with a Structural VAR Approach,” Journal of Monetary Economics, 45, 561-586. and Sandri, D., 2016, “Capital Controls or Macroprudential Regulation?” Journal of International Economics, 99(S1), 27-42.

Kwon, G., Choi, I., and A. Tilton, 2016, "Lower Bound for Interest Rates in Asia? - Assessing the Constraints," Goldman Sachs, Asia Economic Analyst, July 8, 2016.

Laseen, S., Pescatori, A., and Turunen, J., 2015, "Systemic Risk: A New Trade-off for Monetary Policy?" IMF Working Paper 15/142.

Leeper, E., 1991, "Equilibria under 'active' and 'passive' monetary and fiscal policies," Journal of Monetary Economics, 27(1), 129-147.

Lim, C., Columba, F., Costa, A., Kongsamut, P., Otani, A., Saiyid, M., Wezel, T., Wu, X., 2011, "Macroprudential Policy: What Instruments and How to Use Them? Lessons from Country Experiences,” IMF Working Paper 11/238.

Liu, Z. and Spiegel, M., 2015, "Optimal Monetary Policy and Capital Account Restrictions in a Small Open Economy," IMF Economic Review, 63(2), 298-324.

Nedeljkovic, M. and C. Saborowski, 2017, "The Relative Effectiveness of Spot and Derivatives Based Intervention: The Case of Brazil," IMF Working paper 17/11.

Ostry, J.D., A.R. Ghosh, and M. Chamon, 2012, “Two Targets, Two Instruments: Monetary and Exchange Rate Policies in Emerging Market Economies”, IMF Staff Discussion Note No. 12/01, International Monetary Fund.

Quinn, D. 1997, “The Correlates of Change in International Financial Regulation,” American Political Science Review, 91(3), 531-51.

Rey, H., 2015, "Dilemma not Trilemma: the Global Financial Cycle and Monetary Policy Independence," NBER Working Paper 21162.

Ricci, L., and W. Shi, 2016, "Trilemma or Dilemma: Inspecting the Heterogeneous Response of Local Currency Interest Rates to Foreign Rate,” IMF Working Paper 16/47.

Sims, C., 1992, "Interpreting the Macroeconomic Time Series Facts: The Effects of Monetary Policy," European Economic Review, 36(5), 975-1000.

Svirydzenka, K. and Z. Zhang, 2020, "Unintended Consequences of FX Interventions: Dollarization in Emerging Market Economies,” IMF Working Paper, forthcoming.

Woodford, M., 2011, "Simple Analytics of the Government Spending Multiplier," American Economic Journal: Macroeconomics, 3(1), 1-35. 
Wu, J.C. and F.D. Xia, 2016, "Measuring the Macroeconomic Impact of Monetary Policy at the Zero Lower Bound," Journal of Money, Credit and Banking, 48(2-3), 253-291.

Zdzienicka, A., S. Chen, F. Diaz Kalan, S. Laseen, and K. Svirydzenka, 2015, "Effects of Monetary and Macroprudential Policies on Financial Conditions: Evidence form the United States," IMF Working Paper 15/288.

Zhang, L. and E. Zoli, 2014, "Leaning Against the Wind: Macroprudential Policy in Asia" IMF Working Paper 14/22. 